\title{
Bibliotekstilbud i København før de kommunale biblioteker
}

\author{
Lejebiblioteker, klub- og foreningsbiblioteker \\ samt folkebiblioteker ca. 1850-1885
}

Af Kirsten Mosolff

\section{Indledning}

De ældste biblioteker i Danmark var først og fremmest biblioteker for de lærde. Op igennem 1700-årene begyndte nye strømninger af idéer og interesser at komme til landet. Dette resulterede også i ændringer på biblioteksområdet, bl.a. på grund af en større læselyst, ikke bare blandt de bedre stillede, men også hos den almene befolkning. Der var nu begyndt at blive flere skoler, så læsefærdighederne blandt den almene befolkning var blevet bedre. Med skoleloven i 1814 blev en endnu større del af befolkningen i stand til at læse.

De eksisterende biblioteker var enten ikke åbne for offentligheden, eller også var deres materialegrundlag for svært tilgængeligt for størstedelen af befolkningen. Dette resulterede bl.a. i oprettelsen af nye typer biblioteker, et fænomen som tog sin begyndelse i 1700årene. Disse biblioteker kunne have mange navne, såsom lejebibliotek, folkebogsamling, læsebibliotek, lånebibliotek, læsekreds og læseselskab. En del navne kunne dække over samme type bibliotek, som f.eks. læsebibliotek og lejebibliotek.

Lejebibliotekerne gik i al sin enkelthed ud på, at en person stillede en bogsamling til rådighed, hvor folk betalte for at leje en bog

Kirsten Mosolff, bibliotekar DB 2000. 
i en periode. Lejebibliotekerne dækkede det store behov der var kommet i 1700-årene, hvor lysten til at læse havde bredt sig til alle samfundslag. Bøger var nok begyndt at blive billigere, men for mange var det stadig en dyr investering. Derfor skaffede lejebibliotekerne mange mennesker adgang til, for en overkommelig pris, at få læst adskillige bøger. Det sidste lejebibliotek lukkede i 1900-årene. Men da var der for længst kommet en bibliotekslov, og folkebibliotekerne havde taget over.

Borgerskabet havde nok benyttet sig af lejebibliotekerne, når de ønskede lettere litteratur, men frem for alt samlede de sig op gennem 1800-årene i klubber og selskaber, såsom Læseselskabet Athenæum og Kongens Klub. De første 'clubs', som de blev kaldt i starten, oprettedes i sidste del af 1700-årene; de blev allerede fra begyndelsen meget populære og fik deres største udbredelse i første halvdel af 1800-årene. Næsten alle klubberne havde et bibliotek, men de var i lige så høj grad et samlingssted, hvor man kunne spille, konversere og more sig.

Hvor klubber, selskaber og foreninger før havde været for borgerskabet, stiftede håndværkere, arbejdere og kvinder også klubber og selskaber i sidste halvdel af århundredet. Og i modsætning til borgerskabets klubber og selskaber, har mange af disse eksisteret til langt ind i 1900-årene.

Lejebibliotekers, læseselskabers og klubbers sammenhæng med tidens politiske og kulturelle strømninger er kendt og beskrevet før. Formålet med denne artikel er at gå dybere og beskrive de enkelte bibliotekers organisation, samlinger, udlånspolitik og brugergrupper for at få et billede af biblioteksudbuddet i København før dannelsen af det kommunale biblioteksvæsen.

Folkebibliotekerne har i dag en betydning som biblioteker for alle, men da de første folkebiblioteker kom i sidste del af 1800-årene, var det biblioteker tiltænkt de laveste klasser. Det skulle være biblioteker der kunne virke i folkeoplysningens og folkeopdragelsens tjeneste. Der havde været diskussioner om lejebibliotekernes dårlige indflydelse på folk, lige fra de første blev oprettet. Og med folkebibliotekerne kunne man nu udvælge den rette litteratur. Selv efter at folkebibliotekerne i løbet af 1900-årene ændrede karakter, 
havde borgerskabet svært ved at benytte sig af dem, da tankerne om at folkebibliotekerne var for de lavere klasser hang ved.

\section{Lejebiblioteker (se fortegnelse i bilag 1)}

Lejebibliotekerne var en bibliotekstype der stort set kun forekom i de større byer. I Danmark blev de første lejebiblioteker oprettet i løbet af 1700-årene, først og fremmest i byer som København, Âlborg og Odense, men i slutningen af 1700-årene og op igennem 1800-årene fik de stor udbredelse i mange byer landet over. Et af de første lejebiblioteker i København var Venninghausens, der var oprettet af en tysk tjener omkring 1725 og fortsatte med at eksistere resten af 1700-årene. Venninghausens lejebibliotek var nok også det mest kendte af slagsen og omtales i flere bøger fra samtiden.

Selv om lejebibliotekerne bliver opfattet som én bibliotekstype, kunne der være stor forskel på dem. Der var både privatpersoner uden tilknytning til bogbranchen og boghandlere, som havde lejebiblioteker. En del privatpersoner oprettede et lejebibliotek for at tjene lidt ekstra på en måde som mange troede var nem, og der var mange af disse personer der udlånte bøgerne fra deres private lejlighed. Konkurrencen blandt lejebibliotekerne var dog hård, og mange måtte lukke deres bibliotek efter et par år i branchen eller sælge til andre. At være ejer af et lejebibliotek var ikke nogen guldgrube, og der var ingen der blev rig af at ernære sig ved dette erhverv. Der var dog også lejebiblioteker der eksisterede i årtier, som Andersens lejebibliotek der åbnede i 1804 og først lukkede omkring 1860, eller H. C. Bakkes lejebibliotek der eksisterede fra 1841 til 1922, i de sidste årtier dog med to andre ejere end Bakke selv, som døde i 1884.

Et par af de privatpersoner der oprettede lejebiblioteker, var jomfru J. S. Jordan og enke Zerline Levin, der også var blandt de fă kvinder i branchen. Jomfru Jordan havde fra 1848 til 1892 et lejebibliotek i Pilestræde 97, der bestod af en samling på ca. 3.500 bøger. Enkefru Levins lejebibliotek var kun på ca. 1.500 bind.Til gengæld reklamerede hun med også at have tyske, engelske og franske bøger, selvom hovedparten var på dansk. Hendes bibliotek i Klosterstræde 23 eksisterede fra 1865 til 1901. Begge disse kvinder 
havde lejebibliotekerne som fuldtidsbeskæftigelse, med åbningstider fra kl. 9 om morgenen til $\mathrm{kl} .8$ om aftenen, og holdt kun lukket sønog helligdage.

Blandt boghandlerne var der adskillige der havde et lejebibliotek i tilknytning til deres boghandel, men i modsætning til de privatpersoner der var ejere af et lejebibliotek, var det ikke udelukkende for at tjene penge at boghandlerne drev et sådant bibliotek, de brugte nemlig også deres lejebibliotek som en slags reklame for at tiltrække kunder til deres boghandel. I lejebiblioteket kunne de præsentere de nye bøger, og de reklamerede da også med at de bøger der kunne lånes i biblioteket desuden kunne købes i deres boghandel. En del reklamerede med bøger på udenlandsk, såsom det Riiseske lejebibliotek der udsendte en katalog over franske bøger, Catalogue des livres français, eller Ludvig Jordan der reklamerede med at have et stort udvalg af engelske bøger i sit lejebibliotek.

Lejebibliotekerne kunne variere meget i størrelsen. Fra sidste halvdel af 1800-årene kendes et bibliotek på kun 322 bind, og der kendes store biblioteker på 11.000 bind, men det mest almindelige var et antal på 1.500-3.000 bind. ${ }^{1}$ Denne tendens afspejler sig også i de københavnske lejebiblioteker, hvor det normale var et bindantal på 2.000-4.000. Fra første halvdel af 1800-årene kendes der dog til endnu større lejebiblioteker. Gerhard Bonniers lejebibliotek reklamerede $i$ en katalog fra 1825 med at være i besiddelse af 20.000 bind. ${ }^{2}$ Men Bonniers bibliotek går også for at være perlen blandt lejebibliotekerne, ikke bare hvad angår størrelsen, men også når det kommer til det rent indholdsmæssige.

Lejebibliotekerne havde, lige fra de første så dagens lys, måttet høre for deres på alle måder smudsige litteratur. Op igennem 1800årene måtte de ofte stå for skud, når moralisterne kom med indlæg i byens aviser om de skadelige og demoraliserende lejebiblioteker. En af de ting der afstedkom flest kommentarer var netop lejebibliotekernes bogvalg, som moralisterne mente næsten udelukkende bestod af dårlige morskabsromaner, der virkede fordærvende på læsernes moral, og især på de unge læsere. Moralisterne så netop disse bøger som en vigtig årsag til, at mange unge faldt i fordærv: 
'Disse giftige fostre af en skiden indbildningskraft sniger om i mørket, fra hus til hus, fra vrå til vrå, som oftest, håber :jeg, mod forældrenes vilje, og tænder en ild hos den unge alder, hvis hjerte står åbent for ethvert indtryk, som ingen moral, ingen kærlig eller faderlig formaning formår at udslette siden. Vor ungdom forvandles til kraftløse oldinge og nervesyge kællinger, førend de har været raske ynglinge og sunde piger. Vi ser så mangen en skøn yngling, så mangen fager pige visne og blegne i det tyvende år, og gatter vi årsagen tidlig hemmelig vellyst, glemmer vi, hvor skylden må lægges, nemlig især på usund læsning.' Efter denne svada opfordres forældrene $\mathrm{i} ø v$ rigt til at holde et vågent øje med deres børn og hvad de læser. ${ }^{3}$

Der var ikke meget faglitteratur at finde blandt lejebibliotekernes materiale, som mest bestod af romaner, noveller, fortællinger, digte, skuespil og rejsebeskrivelser, men man må tænke på at lejebibliotekernes målsætning først og fremmest var kommerciel. Ejerne havde ingen store flotte tanker om folkeoplysning og belærende litteratur, deres hensigt var som med enhver anden forretning at tjene penge. Dette kunne bedst gøres når man gav folk den litteratur de var interesserede $i$, hvilket på det tidspunkt mest drejede sig om skønlitteratur, samt rejsebeskrivelser der var yderst populære i 1800 årene. Dette billede tegner sig i øvrigt også for Københavns Kommunes Folkebiblioteker, når man ser på den litteratur de var $\mathrm{i}$ besiddelse af da de begyndte, og hvilken type litteratur der var størst udlån i. I Københavns Kommunes Folkebiblioteker måtte der frem til 1909 lånes 1 bog, fra 1909 til 1913 måtte der lånes 2 bøger hvis den ene var faglitteratur, og først fra 1913 måtte der lånes 2 bøger uden hensyn til om det var fag- eller skønlitteratur. Det var i øvrigt også i 1913, at det blev gratis at låne bøger i kommunens folkebiblioteker.

Kærlighed og spænding var specielt populære emner, når det gjaldt lejebibliotekernes læsestof, og visse lejebiblioteker har sikkert haft et større udvalg end andre af den litteratur moralisterne kaldte dårlig. Men der var ikke kun underlødig og dårlig litteratur i lejebibliotekernes udbud, også mange af datidens store og populære forfattere var at finde, bl.a. La Fontaine, Spiesz, J. F. Cooper, Walter Scott, B. S. 
Ingemann, Oehlenschläger, J. L. Heiberg, J. Austen, Charles Dickens, E. A. Poe, W. M. Thackeray, G. Eliot, Victor Hugo og Alexandre Dumas. Desuden reklamerede et par stykker i deres katalog med udlån af skolebøger, bl.a. Ludvig Jordans lejebibliotek i Silkegade.

Lejebibliotekerne udsendte kataloger over deres samling, samt tillæg til katalogerne med nye tilføjelser. Disse var som regel ordnet alfabetisk efter forfatter, og tog ingen hensyn til de forskellige typer af litteratur. Kataloger og tillæg kunne købes i bibliotekerne, og fra disse kataloger skulle der skrives en liste over de bøger man ønskede at låne, da ingen af lejebibliotekerne havde åbne hylder. Denne liste skulle være på et sted mellem 10 og 25 bøger, for at give lejebiblioteket noget at vælge imellem. Der var stort udlån på bøgerne, og mange af bøgerne fandtes kun i et eksemplar, derfor var der ingen garanti for at bøgerne var hjemme.

Som med alt andet omkring lejebibliotekerne varierede også pris og åbningstider en del (se datidens møntsystem i bilag 1). Den mest almindelige pris var for lån af en bog 8 skilling for en uge, 1 mark 8 skilling for en måned og 4 mark pr. kvartal. For to bøger steg prisen til 12 skilling for en uge, 2 mark for en måned og 2 rigsdaler pr. kvartal. Andersens lejebibliotek i St. Helliggeiststræde hørte til blandt de dyreste med sin pris på 1 mark for en uge, 4 mark for en måned og 1 rigsdaler 4 mark pr. kvartal for leje af en bog. Lejebibliotekerne krævede betalingen forud, og desuden skulle der betales depositum på 1-2 rigsdaler eller en ting med tilsvarende værdi. Mange steder kunne bøgerne kun lånes i 14 dage, og nye bøger kun i 8 dage.

Lejebibliotekerne havde lånere fra alle samfundslag, selv om mange fra de bedre lag ikke skiltede så meget med at de lånte bøger et sådant sted. Lejebibliotekerne var som nævnt ikke anset for særlig pæne steder, bortset fra et par enkelte stykker som f.eks. Bonniers lejebibliotek. Størstedelen af lånerne var at finde blandt arbejderne og håndværkerne, og selv om der var kommet en skolelov i 1814, var det måske alligevel begrænset hvor stor læse- og sprogmæssig kunnen mange af disse mennesker havde. Det var mennesker med en lang og ofte hård arbejdsdag, som ønskede let- 
læselig og letforståelig litteratur der gerne måtte være spændende. Når moralisterne taler om det fordærvelige i bøger om kærlighed og spænding, var det netop det der var ønsket hos mange. En bog de kunne leve sig ind i, og for nogle timer glemme hverdagen.

Op igennem 1800-årene lå der næsten konstant 15-20 lejebiblioteker i København, der i midten af århundredet var en by med omkring 140.000 indbyggere. Men midt i 1860'erne begyndte antallet af lejebiblioteker at falde, denne udvikling fortsatte, og ved udgangen af århundredet var der kun en håndfuld tilbage. Det sidste lejebibliotek lukkede dog først omkring 2 . verdenskrig.

\section{K. Andersen}

K. Andersens lejebibliotek blev oprettet i 1804 og lukkede først omkring 1860. Det tilhørte dermed den kategori af lejebiblioteker, der eksisterede over en lang periode. Lejebiblioteket var blandt de største i København, men det var samtidig et af de dyreste, med priser der var ca. det dobbelte af andre lejebibliotekers.

Andersens lejebibliotek var blandt de biblioteker, der med navn blev udhængt i aviserne. I 1820'erne blev der skrevet nogle artikler i Foedrelandsvennen. Artiklerne var ikke var skrevet af tidens moralister, men derimod af en ivrig benytter af lejebibliotekerne. Fra disse artikler kan man forstå, at Andersens lejebibliotek havde bøger med et rimeligt pænt udseende, i modsætning til mange andre, især små lejebiblioteker, der kunne have en samling af fedtede og yderst uappetitlige bøger.

Forfatteren beklager sig derimod over Andersens kataloger, som ikke holder hvad de lover. Der er ikke kommet tillæg til katalogen så ofte som lovet, og biblioteket indeholder heller ikke så mange titler som der reklameres med. Selv om katalogen indeholder numre op til 12.000, kan man se at der faktisk kun er halvt så mange. Desuden synes forfatteren, at der indkøbes for få nye tyske morskabsbøger og tidsskrifter, ligesom han også er utilfreds med åbningstiderne, der kun er på 6 timer om dagen, i modsætning til de fleste andre lejebiblioteker der har åbent i 10-12 timer. Og desuden kan man i Andersens lejebibliotek kun ombytte bøger en gang om dagen. ${ }^{4}$ 


\section{H. H.J. Lynge}

Herman Henrik Julius Lynge (1822-97) var en af de helt store inden for antikvarboghandel, til gengæld vakte de lejebiblioteker han kom i besiddelse af ikke den samme interesse, og de nød derfor ikke godt af Lynges store talent for bøger.

Herman Lynge var ikke bare kendt for sit store forretningstalent, men også som en venlig mand der til tider kunne være ganske gavmild. Han var kendt for altid at betale kontant og ikke forlange kredit, derfor havde han heller ikke selv store muligheder for at yde kredit til andre. Til gengæld omgik han sine egne handelsprincipper på mange måder. Det fortælles at han bl.a. lånte vennen Christian Winther penge på en speciel måde. Han købte et udvalg af digterens bøger, for derefter at opbevare dem indpakket indtil Winther havde råd til at købe dem tilbage til samme pris.

Herman Lynge begyndte sin læretid hos C. T. Sæbye, der havde forretning og lejebibliotek i Gothersgade 25 (fra $1860 \mathrm{nr}$. 10). Sæbye reklamerede i sin katalog fra 1833 med at have både danske (84 sider), tyske (46 sider), franske ( 7 sider) og engelske $(7$ sider) morskabsbøger i sit lejebibliotek. Da Sæbye døde i 1844, overtog hans bror, der var guldsmed, forretningen. Da han ikke havde det store kendskab til boghandel, bad han den kun 22-årige Herman Lynge om at bestyre boghandel og lejebibliotek. I 1853 havde Lynge făet penge nok til at købe den Sæbyeske forretning, til en pris på 1.000 rigsdaler. Herman Lynge var dog mere interesseret $i$ den antikvariske boghandel end i lejebiblioteket, som han lukkede året efter; bogbestanden lod han indgå i antikvariatet.

I 1853 døde N. C. Ditlewsen, der havde boghandel og lejebibliotek i Købmagergade 49 (efter 1860 nr. 45). Lynge overtog denne forretning med både bogbestand og lokaler, kun ca. $1 / 2$ år efter at han havde overtaget den Sæbyeske forretning. I modsætning til det Sæbyeske lejebibliotek blev Ditlewsens drevet videre af Lynge. Det varede dog ikke mange år, før også dette måtte lukke.

Der var også andre måder, hvorpå Lynge var til hjælp for bibliotekerne. Han reklamerede nemlig med, at han kunne fremskaffe selv vanskelige bogønsker til kunderne, som også talte mange danske og udenlandske biblioteker. Lynge forærede bl.a. Det Kongelige 
Ludvig Jordans boghandel og lejebibliotek $i$

Silkegade 4 ca. 1900.

(Det Kongelige Bibliotek. Billedsamlingen)

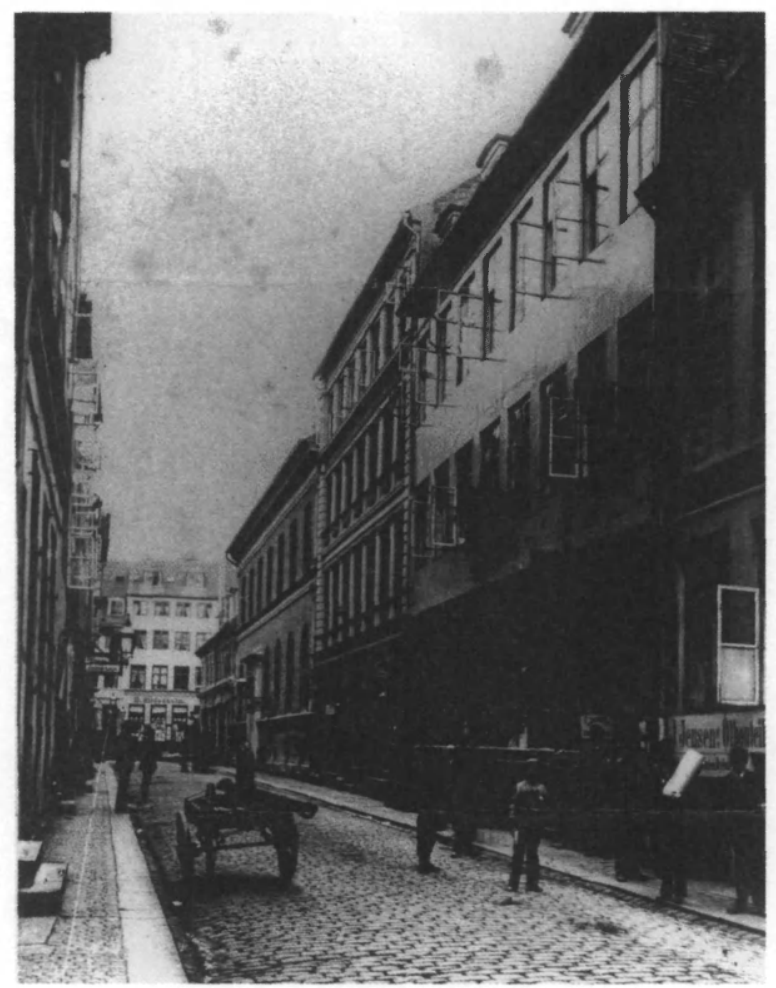

Bibliotek et eksemplar af Det nye Testamente, med noter af Søren Kierkegaard.

\section{Ludvig Jordan}

Heinrich Ludvig Jordan (1813-89) var ejer af en forlagsboghandel og et lejebibliotek der åbnede i 1838. Lejebiblioteket blev et af de mest kendte i København på den tid, måske især efter 1858 hvor Jordan flyttede boghandel og bibliotek til Silkegade 4.

Ludvig Jordan var dog især kendt for sin forlagsvirksomhed, der hovedsagelig drejede sig om føljetoner. På det felt var han nok den største i branchen, og i forbindelse med møntskiftet i 1875 udgav han en katalog med ca. 1.000 titler. Ludvig Jordan havde også et godt øje for, hvilken slags litteratur der var efterspurgt på lejebibliotekerne. Og når det gjaldt føljetoner var han storleverandør, ikke 
bare til sit eget bibliotek, men også til andre lejebiblioteker. Ludvig Jordan sørgede selv for at mange føljetoner blev oversat, hvilket han bl.a. gjorde ved ikke at bruge alt for dyr arbejdskraft.

Ludvig Jordans lejebibliotek var ret stort med sine ca. 4.000 bind, og han reklamerede desuden med at have skolebøger og et stort udvalg af engelske bøger i sit lejebibliotek. Han udsendte bl.a.i 1879 en katalog over lejebibliotekets engelsksprogede litteratur, som omfattede ca. 500 titler. Hvad priser angår, hørte Ludvig Jordans lejebibliotek til blandt de dyreste, selv om det ikke var helt så dyrt som Andersens. Til gengæld kunne der byttes bøger så ofte det var ønsket.

Efter Ludvig Jordans død i 1898 blev hans forretning og lejebibliotek overtaget af Christian Flor og Peter Engberg. Lejebiblioteket blev videreført indtil 1916.

\section{H. C. Bakke}

Hans Christian Bakke (1815-84) blev uddannet som typograf hos Gerhard Bonnier, og efter endt uddannelse blev han i faget i nogle år. Han besluttede dog at starte for sig selv, på samme måde som Bonnier havde gjort i sin tid, nemlig ved at oprette et lejebibliotek. Dette lejebibliotek blev åbnet 19. oktober 1841 i Møntergade 30, og et par år efter åbnede han også en boghandel på samme adresse. I 1848 flyttet han firmaet til Møntergade 27, hvor det blev liggende til efter hans død i 1884. Biblioteket eksisterede i godt 80 år, og blev først lukket i 1922. Dermed er det et af de længst eksisterende lejebiblioteker i København. Efter Bakkes død i 1884 blev boghandel og lejebibliotek overtaget af hans lærling og medhjælper Albert Richter, og efter dennes død i 1899 blev firmaet overtaget af Johan Ernst Wismann.

Ifølge Søren Vasegaard er håndbøgerne fra Bakkes lejebibliotek gået tabt, men ved hjælp af en protokol, der går tilbage til 1847, kan man danne sig et billede af hvordan lejebiblioteket blev drevet. I denne protokol er hvert lån blevet indskrevet, men kun ved knap halvdelen er der skrevet stillingsbetegnelse. Mange mennesker var nemlig kun lånere $\mathrm{i}$ kortere perioder, og ved disse personer står der som regel ingen stilling.Ved hjælp af stillingsbetegnelserne kan man danne sig et ganske godt billede af hvem der lånte bøger. Lånerne 
var folk fra alle samfundsgrupper: Murerlærlinge, løjtnanter, fabrikanter, skuespillere, malere, brændevinsbrændere, skolelærere, proprietærer (fra landet), tobaksarbejdere, billedhuggere, grever, barbersvende, jurister, kaptajner, instrumentmagere, studenter osv. Ved de kvindelige lånere står der jomfru, frøken, madame eller frue, og man må gå ud fra, at dette har været efter deres sociale status.

For at leje bøger måtte der lægges pant, hvilket specielt gjaldt for de lånere som ikke var faste kunder. Dette pant var på 2 rigsdaler, men der kunne også lægges andre ting end penge $\mathrm{i}$ pant. I protokollen står bl.a. teskeer, ringe, kikkerter, dolke, bøger, armbånd og brocher opført som pant. Prisen for at leje bøger afhang af lejemålets længde, men ifølge Vasegaard kunne prisen være ligeså uensartet som pantet. F.eks. er der opført disse priser for lejemål:

$\begin{array}{llc}\text { Leje af } 1 \text { bog } & 16 \text { feb. til } 26 \text { feb. 1849: } & 16 \text { skilling } \\ \text { Leje af } 1 \text { bog } & 20 \text { sept. til } 4 \text { jan. 1850: } & 88 \text { skilling } \\ \text { Leje af } 1 \text { bog } & 10 \text { jan. til } 11 \text { feb. 1850: } & 24 \text { skilling } \\ \text { Leje af } 1 \text { bog } & 16 \text { okt. } 1849 \text { til 27 aug. 52: } & 8 \text { mark }\end{array}$

Desuden er der indført at en låner har betalt 2 rigsdaler for leje af 1 bog i 8 måneder, og at en skuespiller har betalt en gæld på 3 rigsdaler og 2 mark, men der står ikke for hvor mange bøger eller $i$ hvor lang tid bøgerne har været lånt.

Hvis man ser på katalogen over bogsamlingen i Bakkes lejebibliotek fra 1860, kan man se at der faktisk var faste priser:

$\begin{array}{lrll} & \text { pr. uge } & \text { pr. måned } & \text { pr. kvartal } \\ 1 \text { bog } & 8 \mathrm{sk} . & 1 \mathrm{mk} .8 \mathrm{sk} . & 2 \mathrm{mk} . \\ 2 \mathrm{bøger} & 12 \mathrm{sk} . & 2 \mathrm{mk} . & 1 \mathrm{rd} .\end{array}$

For 3 bøger eller flere betales i forhold hertil.

Problemet med protokollen er, at der ikke står opført hvilke bøger folk har lånt. I mange lejebiblioteker var der nemlig forskel på, hvor lang tid gamle og nye bøger kunne lånes. Det kan derfor være svært at fastslå årsagen til denne forskel mellem priserne $\mathrm{i}$ kataloget og priserne i protokollen. Og i modsætning til hvad protokollen anty- 
der, står der i katalogen at der skal betales forud. Uden de egentlige regnskabsbøger kan disse tilsyneladende uregelmæssigheder ikke forklares. Måske har kun en del af personerne betalt et beløb forud.

\section{Immanuel Rée}

Når det drejer sig om Immanuel Rée (1845-1920), kendes der ikke særlig meget til hans tid som ejer af et lejebibliotek. Faktisk er der ikke mange oplysninger om, hvad han foretog sig i tiden 1881 til 1886. Af Kraks vejviser fremgår, at han i denne tidsperiode er opført som ejer af et lejebibliotek i Lille Kirkestræde 5.

Immanuel Rée, der i 1870 åbnede forlags- og kommissionsvirksomhed, var en mand med dristighed og gåpåmod. Han var ikke bange for at introducere nye forfattere på det danske marked, som bl.a. Émile Zola og Paul Heyse. Rée var storannoncør i Boghandlertidende og han kom tit med indlæg i bladet, men han var også en stridbar mand og når han gjorde noget, kunne det ses og høres. Det resulterede $i$ at han blev involveret i flere konflikter. I 1871 besluttede Immanuel Rée, at han ville udgive en oversættelse af John Fosters Dickens' biografi The Life of Charles Dickens. Men på det tidspunkt var F. H. Eibe forlægger for Dickens samlede værker, og han mente bogen hørte til hos ham. Da ingen af de to mænd ville give sig, resulterede det $\mathrm{i}$ to udgaver af bogen: En oversættelse for Rée ved F. C. Sørensen, og en oversættelse for Eibe ved L. Moltke.

I 1875 kom Rée i strid igen, denne gang med V. Hegel og George Brandes, om Paul Heyses roman Im Paradiese. Heyse havde bestemt at han ville have romanen udgivet af Gyldendal, men da Rée havde udgivet flere af Heyses noveller, mente han at han havde ret til også at udgive romanen. Da den forud for den samlede udgave blev udsendt som føljeton i et dagblad, besluttede Rée sig for at bruge denne udgave som forlæg, selv om der manglede flere afsnit, for derved at komme først med sin udgivelse. Det kom herved til et verbalt slagsmål i dagbladene, der i lige så høj grad udartede sig til en personlig hetz mod Brandes, da hans modstandere blandede sig i debatten. 
I 1881 kom Immanuel Rées forlag under administration og blev derefter opkøbt af V. Pio. Helt ude af bogbranchen var Rée dog ikke, for mellem 1881 og 1886 ernærede han sig som ejer af et lejebibliotek i København. Immanuel Rée skiftede i 1886 til rejsebranchen og flyttede til Stockholm.

\section{E. L. Thaarup}

Eduard Ludvig Thaarup (1811-88) begyndte sin læretid hos C. Steen og Gyldendal. Men han grundlagde allerede i 1833 sin forlags- og kommissionsvirksomhed, der med tiden blev en af de største. Blandt det første han udgav, var Dansk Pennig Magazin til nyttige Kundskabers Udbredelse, hvis forbillede var det engelske Penny Magazine. Thaarups magasin udkom i årene 1834-38 og havde ved ophøret udsendt 146 numre.

Thaarup var lidt af en moralist, der tit kom med indlæg i bladene, hvor han svang pisken over boghandlerbranchen. Som ejer af et lejebibliotek eksisterede han kun kort tid, nemlig 1862-67, til gengæld varThaarup en stor samler hele livet igennem, hvilket flere andre biblioteker nød godt af. Han forærede bl.a. kostbare gaver til både Det Kongelige Bibliotek og Universitetsbiblioteket. Ved E. L. Thaarups død i 1888 blev hans kommissionsvirksomhed videreført af sønnen Alex, mens forlaget blev solgt til Lybecker \& Meyer.

\section{Folkebiblioteker-se fortegnelse i bilag 2}

I løbet af 1870 'erne begyndte der at dukke folkebiblioteker op i København. Dette var en helt ny type biblioteker, som ikke må forveksles med de senere kommunalt ejede folkebiblioteker. Idéerne og grundholdningerne i disse biblioteker var dog de samme, som senere var at finde i de kommunale folkebiblioteker. Tanker om folkeoplysning samt god belærende litteratur, der specielt var beregnet for den mindrebemidlede del af befolkningen.

Det første 'københavnske' folkebibliotek var Frederiksberg Sogns Folkebibliotek, der åbnede i 1870. Det havde frem til 1879 til huse på Vesterbrogade, hvorefter det flyttede til Gasværksvej 1. I årene 1870 til 1880 blev der åbnet fem folkebiblioteker. Ud over Frederiksberg Sogns Folkebibliotek var det Amagerlands Folkebi- 


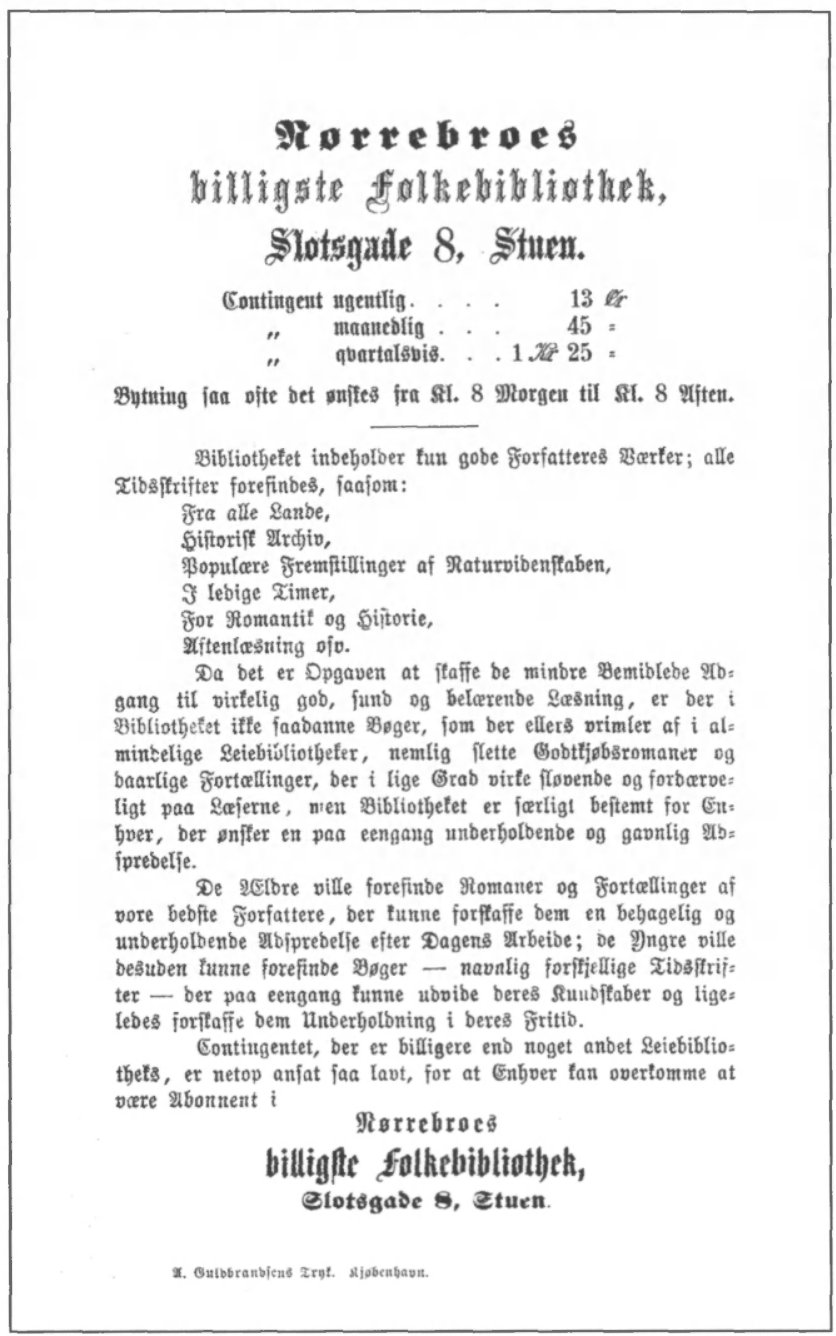

Norrebroes billigste

Folkebibliothek.

(Efter Norrebroes

billigste Folke-

bibliothek. Kbhun.

1881.)

bliotek i Sundbyvester, Brodersamfundets Folkebibliotek i Krokodillegade, Christianshavns Folkebibliotek i Sankt Annægade 39 og Nørrebroes billigste Folkebibliothek der lå i Slotsgade 8.

Nørrebroes billigste Folkebibliothek var meget mulig det billigste på Nørrebro, men i forhold til de andre folkebiblioteker var det klart det dyreste. Priserne på Nørrebros folkebibliotek var mere end dobbelt så høje som på de andre folkebiblioteker. Som eksempel 
kan nævnes, at prisen for et kvartal var $1 \mathrm{kr}$. og 25 øre, samme pris som det kostede for et helt år på Christianshavns Folkebibliotek, der var det billigste.

Disse folkebiblioteker fungerede helt anderledes end lejebibliotekerne, ikke bare hvad angik materialevalg, men også når det kom til styreformen. Selv om bibliotekerne var oprettet på forskelligt grundlag, havde de alle en bestyrelse, der i fællesskab stod for bibliotekets indhold. I Kraks vejviser står der direkte, at Frederiksbergs folkebibliotek hørte under sognets understøttelse. Men ser man på bestyrelsen for Christianshavns og Brodersamfundets folkebiblioteker, kan man se en overensstemmelse mellem bibliotekernes bestyrelse og et par afdelingsbestyrelser under Københavns Understøttelsesforening. Formanden for Christianshavns afdeling var fra 187499 pastor J. C. Holck, og for Gammelholms afdeling var pastor D. C. Prior formand i årene 1874-77.

Amagerlands Folkebibliotek blev stiftet af fabrikant Julius Holmblad i 1877 og var beliggende et godt stykke uden for den indre by. Hvor de andre folkebiblioteker lukkede næsten samtidig med åbningen af de kommunale folkebiblioteker i København (1885) og på Frederiksberg (1887), fortsatte dette bibliotek med at eksistere, måske fordi det lå i en anden kommune (Tårnby, senere Sundbyerne). Amagerlands Folkebibliotek blev senere et led i Københavns Kommunes Biblioteker og eksisterer i dag som filial Sundbyvester. Det skete i 1902, da Sundbyerne blev indlemmet i Københavns kommune.

Klubber, saloner, laseselskaber og laseforeninger. - se fortegnelse i bilag 3 I sidste del af 1700-årene begyndte klubber at blive en populær del af det sociale liv. Inspirationen til klubberne var hentet i Tyskland, Frankrig og England. I disse klubber foregik der mange forskellige former for fornøjelser og selskabelighed, såsom billard, skuespil, musikarrangementer og selskaber. Men man konverserede også i klubberne, og emner som bl.a. politik og litteratur blev ofte diskuteret. Selv om hovedformålet var selskabelighed, oprettede mange af klubberne også læsestuer og biblioteker, som i en del tilfælde ale- 
ne havde aviser og tidsskrifter. Men der var andre klubber, som lagde stor vægt på det litterære liv og oprettede store biblioteker.

Klubberne var først og fremmest borgerskabets samlingssted, og vel at mærke et samlingssted for mændene. Kvinderne havde som regel ingen adgang til klubberne, medmindre det var i forbindelse med fester. Denne idé hænger nøje sammen med datidens syn på kvinder, som man mente ikke havde noget at gøre i det offentlige liv. Kvinderne var ikke de eneste der ikke havde adgang til klubberne, en anden gruppe var jøderne. Det var derfor ret usædvanligt, da grosserer Mariboe fik adgang til Drejers Klub, til trods for at han var jøde. Men en af grundene kan være, at han havde råd til at betale punchens dyrebare sammensætning. ${ }^{6}$

Litteraturen, der var at finde i klubbernes biblioteker, bar præg af at være for borgerskabet. Klubbibliotekerne indeholdt som regel en stor del faglitteratur, især om historie, videnskab, geografi og kunst. Bøgerne var som regel på dansk og tysk, men også bøger på engelsk og fransk var at finde. En stor del af bøgerne var de sidste nye på området, da klubberne gerne bragte den nyeste viden om verden til borgerskabet, som derved fik mulighed for at diskutere disse mange nye emner. For at fẩ råd til nye bøger solgte mange klubber deres gamle bøger til medlemmerne eller på auktion. En del af bøgerne blev dog ikke solgt, men indlemmet i klubbens faste bibliotek.

En af de bedst kendte klubber i 1700-årenes København er Drejers Klub, der oprettedes i 1775 og i en årrække havde Søren Gyldendal som kasserer. Klubben blev hurtigt et litterært samlingssted med et pænt stort bibliotek, der i 1780'erne fik syv biblioteksdirektører. Disse biblioteksdirektører stod for udvælgelsen af klubbens bøger og havde hver en ugentlig aften, hvor de passede udlånet. Et af medlemmerne var Johan Clemens Tode, der i 1786 forslog en række af sine venner $i$ klubben at danne Selskabet for Efterslægten.

I Drejers Klub kom det til diskussioner om, hvorvidt det var det selskabelige eller det litterære, der skulle lægges vægt på. Det førte bl.a. til oprettelsen af Kongens Klub, Det forenede Selskab og Den nye Forening. 
Mange små klubber og saloner var rene avislæseindretninger, hvor der simpelthen kun var en læsesal med aviser og tidsskrifter, men der var dog et par stykker af disse der udviklede sig til mere regulære klubber.J. C. F. Brummer havde omkring 1816 en avislæsestue, som senere blev kaldt et lille for-Athenæum. Blok Tøxen åbnede $\mathrm{i}$ 1831 også en læsestue, Aviscabinettet, i St. Kjøbmagergade 70, som foruden danske og udenlandske aviser også indeholdt håndbøger. Prisen var $1 \mathrm{mk}$. pr. gang eller $1 \mathrm{rd}$. om måneden, hvilket var meget dengang. ${ }^{7}$ I Fodrelandet fra $1851 \mathrm{kan}$ man se en annonce for Avis-Salonen, der tydelig viser at den var i besiddelse af andet end blot aviser. Avis-Salonen tog sig også af andet end udlån af litteratur, som man kan se af en anden annonce i samme avis, den havde nemlig også et agentur for ejendomssalg.

Klubberne havde deres største blomstringstid i slutningen af 1700-årene og forste halvdel af 1800-årene, men i sidste halvdel af 1800-tallet er der ikke mange tilbage.

De første læseselskaber dukkede så småt op i 1770'erne, men først i 1790'erne begyndte det rigtigt at tage fart med oprettelsen af mange nye læseselskaber og læsekredse. I modsætning til klubberne var hovedvægten i læseselskaberne ikke lagt på selskabelighed, men på litteratur, både når det gjaldt læsning og konversation om dette emne. Mange af læseselskaberne havde dog en forholdsvis kort levetid, der kunne begrænse sig til kun et par år, fordi de ofte var afhængige af en enkelt mands foretagsomhed.

Læseselskaber gik i deres grundtanke ud på anskaffelse af bøger på andelsbasis, hvor en gruppe slog sig sammen for oprette en bogsamling. Mange boghandlere oprettede læsekredse, hvor indholdet som regel var på et noget højere niveau end lejebibliotekernes. Desuden skulle bøgerne i læsekredsene helst være den nyeste litteratur, i modsætning til lejebibliotekernes udvalg. Når bøgerne havde cirkuleret blandt kredsens medlemmer, kunne de sælges til medlemmerne eller bortauktioneres på samme måde som i klubberne. Der var også læseselskaber der oprettede et fast bibliotek, og indlemmede en del af de gamle bøger i dette. 
Blandt de boghandlere der oprettede læseselskaber var Gyldendal, der i 1815 oprettede et journallæseselskab. Dette selskab bestod af skønlitterære, politiske, geografiske og almene tidsskrifter, fordelt på 18 tyske, 3 franske og 3 engelske. Det var meningen at selskabet skulle hvile i sig selv, bl.a. ved at medlemmerne selv skulle sørge for indkøb, kontorarbejde, regnskab osv., og desuden skulle de også selv sørge for auktionssalg af bøgerne. ${ }^{8}$

Læseselskabet Clio, der var et af den tids mest kendte, blev oprettet i 1815 og var hjemsted for nogle af tidens mest markante personer. I 1820 talte Clio, der var en blanding af en klub og et læseselskab, 104 medlemmer. De nye bøger og tidsskrifter lå fremme i læseværelset de første 14 dage, og derefter kunne de hjemlånes, nye bøger i 8 dage og gamle i 14 dage. Medlemskontingentet var $10 \mathrm{rd}$. om året, og hvis man på ulovlig vis fjernede bøger og tidsskrifter fra læsestue eller bibliotek, fik man en bøde på 1 rd. På grund af dårlig økonomi måtte Clio lukke allerede i 1822.

Der kunne være meget stor forskel på priserne i disse klubber, læseselskaber og læseforeninger. Athenæum, Avis-Salonen og Clio lå absolut i den dyre ende, med henholdsvis $14 \mathrm{rd}$., $12 \mathrm{rd}$. og $10 \mathrm{rd}$. $\mathrm{i}$ årligt kontingent. Hvorimod Den nye Forening kun skulle have 2 rd. om året; desuden kunne man i denne forening vælge at betale 30 rd. på en gang, derved blev man medlem for altid. Udlånsbetingelserne var dog næsten de samme for dem alle, nemlig 14 dages lån af gamle bøger og 8 dages lån af nye bøger.

Mod slutningen af 1800-årene begyndte andre grupper end det mandlige borgerskab også at oprette læseforeninger og læseselskaber. Kvindebevægelsen begyndte at markere sig, bl.a. med ønsker om at fầ større frihed og bedre adgang til uddannelser. Desuden mente kvinderne, at hovedstaden manglede et samlingssted for kvinder, samt et bibliotek og en læsesal. Borgerskabets kvinder anså læsning for et vigtigt middel i kampen for frigørelse, og i 1872 blev Kvindelig Læseforening dannet. Denne forening var mest af alt for borgerskabets kvinder, og der var da heller ikke mange uden for dette samfundslag, der var medlem af foreningen. Læseforeningen blev oprettet på et tidspunkt, hvor der kom skred i kvindesagens 


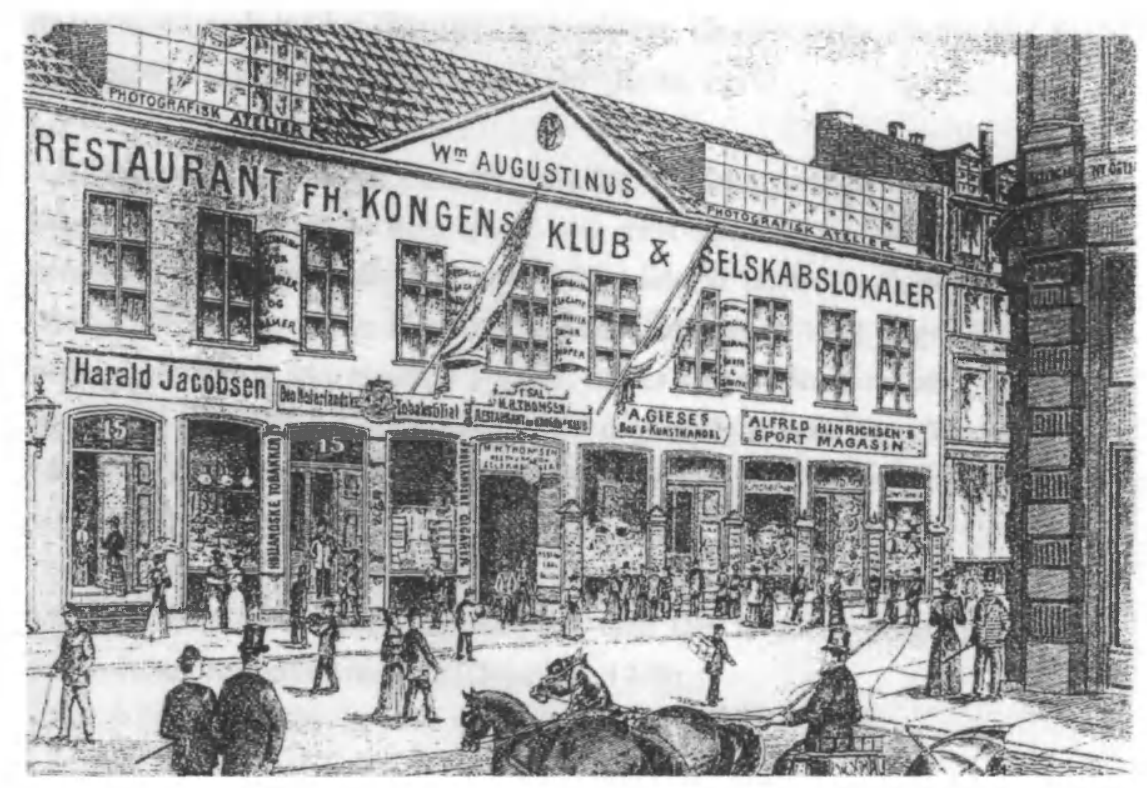

Karl van Manders gård, Østergade nr. 15, ca. 1890.

udvikling. Dansk Kvindesamfund blev stiftet i 1871, bl.a. med det formål 'at hæve kvinden $\mathrm{i}$ åndelig, sædelig og økonomisk henseende'. ${ }^{9}$ En Handelsskole for Kvinder blev oprettet i 1873, men nedlagt igen allerede i 1890 , da man mente at Studentersamfundets aftenundervisning tog sig af samme opgave.

\section{Kongens Klub}

Kongens Klub blev oprettet i 1776 ved en udskillelse fra Drejers Klub, og hed i begyndelsen Selskabet i Mad. Schrecks Gaard. Navnet var taget efter ejeren Gottlieb Schreck, der i 1775 havde købt Karl van Manders gård i Østergade 15. Han havde indrettet gården med en række klub- og koncertlokaler, hvor bl.a. Kongens Klub havde lejet sig ind. Selskabet fik navnet Kongens Klub ved $\mathrm{kgl}$. resolution af 16. nov. 1782. Et navn der hang ved klubben, men også ved huset der beholdt navnet, selv efter at klubben var flyttet. I 1778 kom de første love for klubben. De var underskrevet af 80 
ansete borgere og embedsmænd, deriblandt professor Jens Nørregaard og Rahbek. ${ }^{10}$ Klubben blev hurtigt samlingssted for det bedre borgerskab, og der blev bl.a. holdt koncerter i klubben. Ved sådanne lejligheder havde medlemmerne ret til at medbringe to damer på hver billet.

Omkring 1850 flyttede klubben til nye lokaler, der betød at man nu fik både vinter- og sommerlokaler. I 1846 fik klubben tilladelse til at opføre sommerlokaler på Vesterbrogade 2, og samtidig flyttede den til vinterlokaler på Kongens Nytorv 13. Sommerlokalerne havde klubben indtil 1871, hvor Københavns kommune opsagde lejemålet. Interiøret i Kongens Klub fik med tiden et lidt lurvet udseende; en københavner mindes hvordan klubben så ud i sidste del af 1800-tallet:

'Jeg ser endnu for mig disse små køjer eller kabinetter, hvori restauranten var inddelt. Gamle, defekte sofaer og stole af halfjersernes rædselsfulde facon med falmet, plettet plydsbetræk, et nøddetræs pillespejl, hvis glas var så overridset, at det overhovedet ikke kunne gøre tjeneste som spejl; et gammelt litografi på væggen, et fag forrevne, mølædte gardiner og en snavset gaslampe med to blus - det var hele udstyret. I et par enkelte værelser fandtes et klaver, som led af kronisk hæshed, hvilket ikke var så mærkeligt, da dets indre stadig blev fugtet med spiritus sjatter, der hældtes ned i det."

Klubbens bibliotek var af pæn størrelse og havde som mange andre klubber og selskaber bøger på flere sprog, danske, tyske, engelske og franske. Bøgerne på biblioteket var en blanding af skøn- og faglitteratur samt håndbøger, og der måtte hjemlånes to bøger ad gangen i 14 dage. Bibliotekets åbningstid var dog ikke noget at prale af, da der kun var åbent mandag og torsdag fra 13 til 14. På Det Kongelige Bibliotek er der i dag stadig bevaret en række af klubbens bogfortegnelser. Her kan man bl.a. se, at klubben i 1867 bortauktionerede godt 5000 'gode og velconditionerede bøger'.

Kongens Klub blev senere lagt sammen med Det forenede borgerlige Selskab under navnet Kjøbenhavns Klub. ${ }^{12}$ 
Den bestandig borgerlige Forening

Foreningen blev stiftet i 1798 under navnet Det bestandige borgerlige Selskab, og det var mest af alt en klub, hvis fremmeste formål var at fornøje. Klubben skiftede navn til Den bestandig borgerlige Forening i 1824, da den blev sammensluttet med Det musikaliske Selskab. Fra starten var det, som så mange andre selskaber og klubber, et sted for mænd, og kvinder havde kun adgang i forbindelse med fester. Men der var dem der truede med at danne deres egen klub, hvis kvinderne ikke fik adgang. Derfor blev det bestemt at kvinderne skulle have adgang en dag om ugen, hvilket blev om onsdagen, som også blev foreningens festdag. I foreningens vedtægter hedder det blandt andet, at mændene til fester skal bære handsker, men ikke må bære støvler, for ikke at beskadige damernes klæder og pynt under dansen.

Ved foreningens start blev det bestemt, at der ikke måtte være mere end 150 medlemmer i foreningen, men antallet kunne dog forhøjes af direktionen, hvis den mente det var ønskeligt. Prisen for at være medlem blev sat til 4 rigsdaler årligt, samt 5 rigsdaler $\mathrm{i}$ indskud; desuden skulle der hvert nytår betales 24 skilling til fordeling blandt foreningens betjente.

For at blive optaget som medlem i foreningen skulle man foreslås af en som allerede var medlem. Derefter skulle man komme med en skriftlig ansøgning, der skulle indeholde navn, adresse og stilling. Denne ansøgning skulle afleveres 8 dage før voteringen, og blev man optaget, skulle man indføres i foreningen af sin proponent senest 4 uger efter. Ingen der var blevet afslået som medlem tre gange $\mathrm{i}$ andre selskaber, måtte foreslås som medlem. Der var desuden flere forskellige former for medlemskab, udover de almindelige medlemmer var der æresmedlemmer, rejsende medlemmer, dansende medlemmer og sommermedlemmer.

Foreningens mål gik først og fremmest ud på selskabelighed og konversation, og der skrives da heller ikke meget om foreningens bibliotek. I forhold til foreningens mange andre udgifter er der ikke blevet ofret det helt store på biblioteket. I 1843 hedder det, at der ud over udgifterne til subskriptionerne hvert kvartal skal betales 15 rigsdaler til bibliotekaren, til biblioteksudgifter. Denne var en 
af de 25 embedsmænd, som foreningen havde: 5 direktører, 1 kasserer, 2 revisorer, 3 decisorer, 2 bygningsinspektører, 1 bibliotekar, 2 balinspektører, 2 kegleinspektører, 2 billardinspektører, 3 skydeinspektører, 1 økonomiinspektør og 1 sekretær. Man kan heraf se, hvor meget spil og selskabelighed har betydet for foreningen.

Foreningen havde flere regler for opførsel, og hvis disse blev overtrådt, skulle der betales en bøde. Undtagen ved festlige lejligheder skulle foreningen lukke kl. 11, som det stod skrevet i en generel kongelig ordre fra 1780 (mange klubber så gennem fingrene med hensyn til denne ordre, andre opfordrede blot medlemmerne til at overholde forbudet). Hvis nogen opholdt sig i lokalerne efter dette tidspunkt, skulle der betales mellem 2 skilling og 1 rigsdaler $i$ bøde. Det var desuden forbudt at spille hasard i foreningen, og alt spil var forbudt om søndagen før kl. 16. Når der blev spillet billard, skulle spilleren skrive sig på en ophængt tavle, da der blev spillet efter tur, og når han var færdig med at spille, skulle han skrive sit navn i en billardprotokol. Hvis dette ikke blev overholdt, vankede der en bøde på 8 skilling, samt fratagelse af de penge han havde vundet.

Foreningens lokaler lå gennem det meste af 1800-tallet i Vingårdstræde, men i 1835 bestemte foreningen sig til at købe ejendommen Store Ravnsborg på Nørrebro. Restaurering og indretning af Store Ravnsborg kom til at overstige budgettet, og foreningen måtte derfor låne 6.000 rigsdaler af nogle medlemmer. Da ejendommen stod færdig, havde den i alt kostet 20.000 rigsdaler. Foreningen beholdt samtidig lokalerne iVingårdstræde, der fungerede som vinterlokaler.

I 1858 bestemte foreningen at sæsonens fire baller ikke skulle afholdes i vinterlokalerne, men derimod i Nimb, og at foreningen, der nu var en af de fineste i København, skulle betale portpengene. Til disse fester var der hver gang, iberegnet damer, omkring 300 deltagere.

Men allerede i løbet af 1860 'erne begyndte foreningens økonomi at skrante, bl.a. fordi der var blevet brugt alt for mange penge på fester og fornøjelser. Foreningen havde haft svært ved at finde faste vinterlokaler, siden den i 1850'erne var flyttet ud af lokalerne iVingårdstræde, og det blev nu foreslået også at benytte Store Ravnsborg 
om vinteren. Dette ville mange medlemmer ikke gå med til, da de mente det var for besværligt at komme 'uden for porten' om vinteren. Så foreningen endte med at flytte tilbage til Vingårdstræede, da de lokaler var billigst, men måtte i 1882 benytte Store Ravnsborg både sommer og vinter af økonomiske grunde. Foreningen blev nødsaget til at sælge Store Ravnsborg kort efter, og samtidig solgtes også inventaret for $4.000 \mathrm{kr}$. og biblioteket for $750 \mathrm{kr}$. Foreningen fortsatte efter salget af Store Ravnsborg, i mere ydmyg målestok og med et mere beskedent budget. Dog var formålet stadig morskab og fornøjelser.

\section{Laseselskabet Athenceum}

Læseselskabet Athenæum blev oprettet i 1824 og havde taget navn efter den engelske Athenaeum Club i London, der var stiftet året før. Athenæum var som Clio en blanding af klub og læseselskab og var juvelen blandt disse. I lovene fra 1832 hedder det bl.a., at medlemmerne skal gives adgang 'dels til de fortrinligste eller for øjeblikket mærkelige, indenlandske og fremmede tidender, blade og tidsskrifter, dels sådanne bøger der er af almindelig interesse for dannede mænd, uden i almindelighed udelukkende at henhøre under noget særskilt videnskabsfag'.

Athenæum var for det højere borgerskab, og ønskede derfor at opretholde en vis standard. Enhver, der ønskede optagelse i selskabet, skulle derfor fra et medlem have en skriftlig anmeldelse, der skulle afleveres til formanden. Derefter var det op til selskabets repræsentantskab at optage eller afvise den pågældende person. På denne måde sikrede Athenæum sig mod at der blev optaget uønskede individer i selskabet. Denne optagelsesmåde er meget lig den man skulle igennem, for at blive optaget i Den bestandig borgerlige Forening. Mange yngre mennesker og personer fra det mindre fine borgerskab søgte over i Den borgerlige Læseforening, der var knap så fin.

Athenæum var Københavns dyreste selskab, med et kontingent på $14 \mathrm{rd}$. om året, der i 1877 var steget til $36 \mathrm{kr}$. (18 rd.). Og desuden skulle der betales $4 \mathrm{rd}$. i indtrædelsesgebyr. Tilrejsende kunne få et gratis adgangskort for 8 dage eller et månedskort for $1 \mathrm{rd}$. 


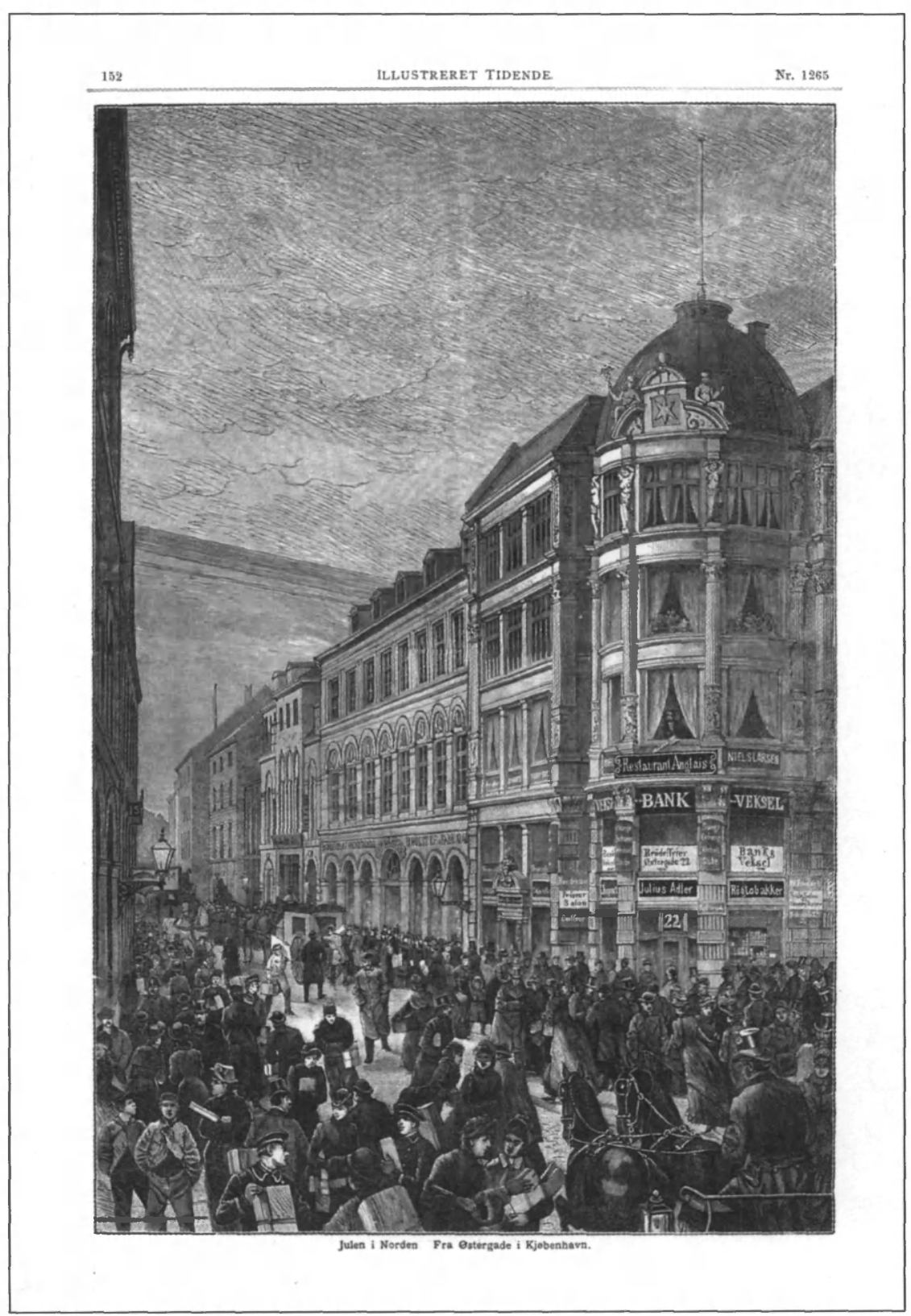

Østergade anno 1883. Athenaum havde lokaler på 1. sal. i nr. 24, som er huset med de buede vinduer. (Illustreret Tidende, 25. årg. nr. 1265, 23. december 1883, side 152) 
Selskabet havde adresse i Østergade 24, skråt over for Kongens Klub, i 9 store og højloftede lokaler, der indeholdt bibliotek, læseværelser, klubværelser, konversationsværelser og konditorværelse. Men det var en dyr adresse, der kostede 1200 rd. i leje om året, samt 100 rd. til maling. Og skønt medlemmerne kom fra de bedre kredse, var det tit vanskeligt at indkassere kontingentet fra medlemmerne; derfor levede Athenæum på et vaklende økonomisk grundlag. Athenæums bibliotek blev hurtigt stort, med de nyeste bøger og et stort antal både danske og udenlandske tidsskrifter. Biblioteket indeholdt en stor mængde faglitteratur, der bl.a. omhandlede teologi, geografi, historie, jura og naturvidenskab. Desuden var biblioteket $\mathrm{i}$ besiddelse af en mindre samling romaner, skuespil og digte, foruden håndbøgerne i læseværelserne. Athenæum var åben fra 9 om morgenen til $11 \mathrm{om}$ aftenen, hvilket dog ikke gjaldt biblioteket, der havde åbent kl. 12-15 og igen kl. 17-20. Selskabet havde mere strikse love end andre selskaber, bl.a. optagelsesreglerne, men også vedrørende benyttelsen af biblioteket. Hvis et medlem blev taget $\mathrm{i}$ at fjerne bøger fra læseværelserne eller biblioteket, fik den pågældende en bøde på $20 \mathrm{kr}$. Anden gang et medlem blev taget i denne foreteelse, blev personen udelukket fra klubben.

\section{Loseindretningen fra 1826}

Læseindretningen fra 1826 blev oprettet af Gyldendal, der annoncerede med at ville anskaffe "de vigtigste nye Bøger og Journaler, med Undtagelse af de strængt videnskabelige”. I 1828 rådede biblioteket over 1.200 bind aktuelt læsestof, der voksede støt gennem hele foreningens eksistens. Læsestoffet omhandlede bl.a. personalhistorie, rejsebeskrivelser, historie og skønlitteratur, der var at finde på dansk, tysk, engelsk og fransk.

En del af Læseindretningens romaner fandtes både i en dansk og en tysk eller engelsk udgave, som bl.a. Walter Scott der fandtes på alle tre sprog. Walter Scott var i øvrigt meget populær i første halvdel af 1800-årene, og i Læseindretningens katalog fra 1835 findes der i alt 261 bind af denne forfatter. Hvor tysk omkring år 1800 havde været det helt dominerende udenlandske sprog, kan man i katalogen fra 1835 se en vækst i litteratur på fransk og især engelsk. 
Det kostede 4 rd. i årlig kontingent at være medlem af Læseindretningen, men da bøgerne blev bragt ud, skulle der også betales budløn oven i kontingentet. Medlemmerne kunne låne 2 bøger ad gangen i 8 dage, men bøgerne skulle rekvireres dagen før man fik dem. Læseindretningen ikke alene udlånte, men solgte også bøger. Ved køb over en vis sum kunne medlemmerne få en rabat, der svarede til det årlige kontingent. Desuden forsøgte Læseindretningen at hente udenbys kunder ved at tilbyde, at disse kunder kunne låne 20 bøger i 2 måneder, dog mod at betale et forhøjet kontingent. ${ }^{13}$

\section{Selskabet for Borgerdyd}

Selskabet for Borgerdyd var som Selskabet for Efterslægten blevet stiftet på baggrund af de oplysningstanker, der var begyndt af florere sidst i 1700-årene. Som Efterslægtsselskabet oprettede Selskabet for Borgerdyd en skole efter moderne fremsynede principper, bl.a. inspireret af Rousseaus værk Emile, der blandt meget andet gjorde op med den gamle skoletradition. Skoleideerne gik bl.a. ud på at indføre flere praktiske fag og nye pædagogiske idealer. Skolen blev snart efter delt i to, en midt i København og en på Christianshavn. Skolerne blev hurtigt efterspurgte blandt borgerskabet, hvilket fortsatte op gennem 1800-årene og videre frem. Skolerne blev først i 1900-årene statsskoler, under navnene Østre Borgerdydsskolen og Vestre Borgerdydsskolen.

Selskabets bibliotek blev grundlagt i 1787, hvilket i øvrigt var samme år som skolens oprettelse. Selskabet havde på denne tid 2.000 bind, men manglede penge til at indrette et bibliotek. Det bibliotek de ønskede at oprette, skulle specielt være indrettet til dem 'som ikke har dyrket de lærde sprog og videnskaber, derfor anskaffes ingen bøger, som enten er skrevet på disse sprog eller kun til brug for de lærde'. ${ }^{14}$ Biblioteket skulle dog ikke gå lejebibliotekerne i bedene, derfor ville det ikke anskaffe alt for megen skønlitteratur, da man jo kunne få denne type andetsteds. Derimod skulle biblioteket lægge vægt på anskaffelsen af oplysende værker, som naturlære, naturhistorie, landøkonomi, fabriks- og manufakturvæsen, handel, bidrag til eget og andre landes historie, samt naturlige og praktiske forhold. Bøgerne skulle desuden være skrevet på en letfattelig må- 
de. ${ }^{15}$ Det var en anonym velgører, der kom selskabet til hjælp med et rentefrit lån på 2.500 rigsdaler, som skulle tilbagebetales med 125 rigsdaler om året. Ved hjælp af disse penge blev der indkøbt 6.000 skrifter. Abraham Kall var dog bange for, at biblioteket ikke kunne betale sig, når man ikke imødekom tidens smag. Han indlemmede derfor sin egen samling på 5-6.000 historiske og skønlitterære skrifter $\mathrm{i}$ biblioteket, for at der kunne blive større søgning.

I modsætning til så mange andre klubber kunne både mænd og kvinder optages i Selskabet for Borgerdyd. Det kostede $4 \mathrm{rd}$. om året at være medlem af selskabet, hvoraf ca. halvdelen gik til biblioteket. Hvis man ikke hvert år forudbetalte for næste år, blev man udelukket af selskabet. Ud over de almindelige regler for betaling og administration af selskabet, var der 25 frivillige vedtægter vedrørende medlemmernes levemåde. Medlemmerne skulle underskrive mindst en af disse vedtægter, som personen så skulle overholde. Vedtægterne var bl.a. begrænsninger af, hvor mange retter der måtte serveres, hvilke klæder der måtte bruges, at man så vidt muligt skulle købe indenlandske produkter og ikke deltage i baller der varede længere end til kl. 24. Tyge Rothe siger bl.a. i sine betragtninger over selskabets formål, at selskabet vil arbejde imod 'brammende ødselhed, imod hver fordærvelig spillelyst og imod svindelhed'.

\section{Kvindelig Laseforening}

Kvindelig Læseforening blev stiftet i 1872 på inspiration af Frederik Bajer, efter at han havde fået kendskab til den svenske Lässalong för Damer, der var åbnet i Stockholm i 1867. I 1871 holdt Bajer et foredrag i Pædagogisk Selskab, hvor han netop pegede på Lässalong för Damer som en inspirationskilde for de danske kvinder. Planen var dog ved at strande på grund af økonomiske vanskeligheder, men blev reddet af Sofie Petersen. Hun henvendte sig til ca. 50 kvinder, deriblandt D. B. Adlers og C. Plougs hustruer, og sammen med Ploug og otte andre mænd fik de udsendt en anmodning om at give et bidrag i form af penge eller bøger, således at der kunne blive oprettet et bibliotek for kvinder.

Foreningen fik stor tilslutning, og da den åbnede i 1872, havde den 72 medlemmer og en bogsamling på 1.007 bind. Dette var et 
ganske udmærket startgrundlag, specielt når man ser på at f.eks. Arbejdernes Læseselskab begyndte med kun 12 medlemmer og 340 bind. Men i modsætning til Arbejdernes Læseselskab kom de fleste af Kvindelig Læseforenings medlemmer fra borgerskabet, og der var mange af tidens mest fremtræedende kvinder som var medlem af foreningen. Grundet formændenes arbejde, opnåede foreningen at fầ statstilskud fra 1879 .

Biblioteket fortsatte med at vokse, og ved foreningens 25 års jubilæum i 1897 havde det 16.000 bind og et udlån på 49.747 bind. Dette fortæller Rosine Heckscher stolt i en artikel i Kvinden og Samfundet, hvor hun til sammenligning oplyser, at i 1895/96 havde Universitetsbiblioteket et udlån på 22.000 bind og Det Kongelige Bibliotek et udlån på 12.000 bind.

Kvindelig Læseforenings bibliotek havde, som næsten alle andre biblioteker på den tid lukkede hylder. Men i modsætning til de fleste andre benyttede biblioteket sig af de lukkede hylder til langt ind i 1900-årene. I 1935 havde biblioteket således kun 3.000 bind på åbne hylder, ud af en samling på godt 90.000 bind. Biblioteket havde både skøn- og faglitteratur, dansk såvel som udenlandsk, samt tidsskrifter og blade. Det største udlån havde biblioteket på skønlitteratur, mens det mest populære blandt faglitteraturen var historie, biografier, geografi og rejsebeskrivelser. Biblioteket havde 14 dages lån på skønlitteratur og 1 måneds lån på andet.Ved åbningen i 1872 havde biblioteket åbent alle hverdage kl. 14-18, men disse åbningstider blev udvidet omkring 1880 til 11-15 og 16-19. På dage hvor der blev holdt foredrag, lukkede udlånet dog kl. 16 .

For at blive ansat i biblioteket skulle man være i besiddelse af almen dannelse samt gode sprog- og skolekundskaber, og man skulle desuden være fyldt 18 år. Efter en prøvetid på 3 måneder kunne man blive antaget som medhjælper i biblioteket, og derefter kunne man evt. blive fastansat som assistent.

Som så mange andre foreninger var Kvindelig Læseforening mere end et bibliotek, idet stedet også fungerede som foredrags- og diskussionsforening. Desuden havde læseforeningen læsekredse tilknyttet, hvor også mænd havde adgang. For at blive medlem af en læsekreds skulle man indtegne sig hos bibliotekaren og angive hvil- 
ket tidsskrift man ønskede at abonnere på. Disse læsekredse ophørte i 1880 'erne og blev først genindført omkring 1910, hvor det bl.a. hedder at formålet er, ved omhyggeligt valg af gode bøger, at opdrage og udvikle medlemmernes smag for god litteratur.

Arbejder- og håndvarkerforeninger - se fortegnelse $i$ bilag 4

I løbet af 1800-årene begyndte også de arbejdende klasser at markere sig. I første omgang var det $\mathrm{i}$ håndværkerstanden, at der begyndte at ske noget, ikke mindst blandt de unge håndværkere der fik en politisk påvirkning fra udlandet. Der opstod hos disse mennesker et voksende ønske om frihed, og det var også blandt dem at en ny foreningsbevægelse begyndte at vokse frem. I disse foreninger diskuteredes blandt andet lavstvang og næringsfrihed.

Begyndelsen kom med Læseforeningen, der blev oprettet i 1836 som et samlingssted for alle disse 'frihedshungrende' mænd, men som Adolf Bauer pointerede, lyder det officielle formål 'at åbne adgang til almennyttig og almeninteressant læsning for alle stænder, men især for den næringsdrivende borger' lidt mere afdæmpet. Efter denne forening blev Industriforeningen i København stiftet i 1838 og Håndværkerdannelsesforeningen, der var udpræget politisk, i 1847.

Hen over midten af 1800-årene begyndte der også at blive større opmærksomhed omkring arbejdernes stilling i samfundet. Dette resulterede i en række arbejderforeninger, der som oftest blev oprettet på initiativ af liberale borgere. Disse var begyndelsen på de nye tanker om folkeoplysning, og deres formål var som regel at fremme arbejdernes oplysning og dannelse og gøre dem til ligeberettigede samfundsborgere på det intellektuelle plan. I $1853 \mathrm{blev}$ Håndværkerdannelsesforeningen og Forening til Arbejdernes Vel, der var oprettet to år tidligere, sammensmeltet til en arbejderforening med C.V. Rimestad som formand. ${ }^{16}$ En anden forening på denne tid var Folkevenners Selskab, der havde major L. Müllen som formand, men hvis egentlige leder var J. A. Hansen. Dette selskabs hovedformål var 'at virke for håndværks- og arbejderklassens åndelige og materielle udvikling'. I 1860 stiftede C.V. Rimestad sin egen arbejderforening, som er et typisk eksempel på de arbejderforeninger der blev oprettet i løbet af 1860'erne. 
Der var også dem der var imod, at arbejderne skulle have denne borgerlige dannelse. Dem der mente at arbejderne ikke havde brug for al denne borgerlige dannelseskultur, men derimod havde brug for deres egen kultur. En kultur der kunne støtte arbejderne i deres daglige liv, gøre dem stærkere og føre til bedre uddannelse. I Socialistiske Blade i 1871 kom Pio med en advarsel til Arbejderforeningen, hvor han bl.a. siger "Lær ham hvorledes han ved de få lovlige midler, der står til hans rådighed, kan beskytte ham mod kapitalens overgreb, giv ham de kundskaber der hører til for at han engang [...] kan hjælpe til at styre den fabrik, han nu kun er et vil:jeløst redskab i". ${ }^{17}$

I slutningen af 1870'erne var arbejderbevægelsen så småt begyndt at blive stærkere, selv om det endnu kun var en begyndende faktor. Arbejderne begyndte at organisere sig og ønskede bl.a. bedre sociale muligheder og større rettigheder. Selv om arbejderbevægelsen mest handlede om det økonomiske aspekt, var man dog også klar over at kundskaber var en vej ud af undertrykkelse. Mottoet for Arbejdsmandenes Fagblad lyder i 1896 "Uvidenhed er Trældom - Kundskab er Magt".

Tankerne om oplysning og uddannelse begyndte nu virkelig at komme til udtryk, ikke bare blandt de gode velmenende borgere, men også i arbejderbevægelsen selv. Dette resulterede i oprettelsen af bl.a. Socialdemokratisk Samfund, der som navnet antyder havde politisk tilknytning, og Arbejdernes Læseforening der ikke havde nogen politisk tilknytning. I 1882 oprettedes Studenterforeningens Aftenundervisning for Arbejdere, hvis hovedformål var at lære arbejderne noget som grundskolen ikke kunne give, i modsæetning til Arbejderforeningen der ønskede at opdrage arbejderne til borgere. Undervisningen omfattede bl.a. dansk, tysk, engelsk, fysik, kemi og historie. Aftenskolen havde fra begyndelsen ca. 1.500 elever, et antal der holdt sig nogenlunde uændret resten af 1800-årene. Hovedparten af eleverne var mandlige faglærte arbejdere, men frafaldet var ret stort.

Arbejdernes Laeseselskab

Arbejdernes Læseselskab blev stiftet i 1879 og arbejdede de første 
mange år under beskedne kår. Ved stiftelsen rådede læseselskabet kun over fầ bind, og der var kun omkring 12 medlemmer. Selskabet ønskede at arbejde $\mathrm{i}$ folkeoplysningens og folkeopdragelsens tjeneste, med et mål der gik ud på 'at sprede kundskab og dannelse ud blandt den arbejdende befolkning'. Selskabets egentlige grundlag kom med en gave fra Socialdemokratisk Samfund på 340 bind samt 5 kr. og 85 øre. Socialdemokratisk Samfund havde måttet give op på grund af manglende tilskud. Arbejdernes Læseselskab var, i modsætning til Socialdemokratisk Samfund, oprettet på et upolitisk grundlag, en holdning der måske hjalp selskabet til at overleve. Selskabet fik dog senere gode forbindelser til det Socialdemokratiske Arbejderparti, idet flere af partiets medlemmer støttede selskabet.

Et år efter stiftelsen blev der trykt et opråb i Morgenbladet og Dags-Avisen, der prøvede at fâ budskabet om Arbejdernes Læseselskab ud. Heri hedder det bl.a. at det er selskabets formål "gennem læsning af nyttige bøger, at hæve småfolk til et højere åndeligt trin i samfundet end det, de nu af mange forskellige grunde indtager" ${ }^{18}$ Det nævnes også at biblioteket talte ca. 400 bind, og at det kostede 20 øre i månedligt kontingent. Biblioteket havde åbent alle hverdage kl. 19-22, og der kunne lånes 1 bog ad gangen i 4 uger. Hvis bogen blev tilbageleveret for sent, kostede det 10 øre i bøde. Der var også en læsestue i tilknytning til biblioteket, hvor der var fremlagt flere aviser, tidsskrifter og ugeblade uden hensyn til partifarven.

Arbejdernes Læseselskab var dog mere end blot et bibliotek. Der blev bl.a. holdt mange foredrag, og med tiden lykkedes det selskabet at fă flere fremtrædende videnskabsmænd, forfattere og kunstnere til at komme. Til disse foredrag kostede det 10 øre at komme ind for alle, der ikke var medlem af selskabet. Selskabet arrangerede også besøg på forskellige museer og institutioner, som i årenes løb blev til flere hundrede. Blandt de steder, selskabet besøgte, var Amalienborg, Absalons borg, Bispebjerg Hospital, Christiansborg, Synagogen og Det kgl. Teater. Selskabet besøgte også steder hvor der normalt ikke var adgang, såsom Vestre Fængsel og Sankt Hans Hospital. Ligesom Selskabets medlemmer fik andre fordele som 


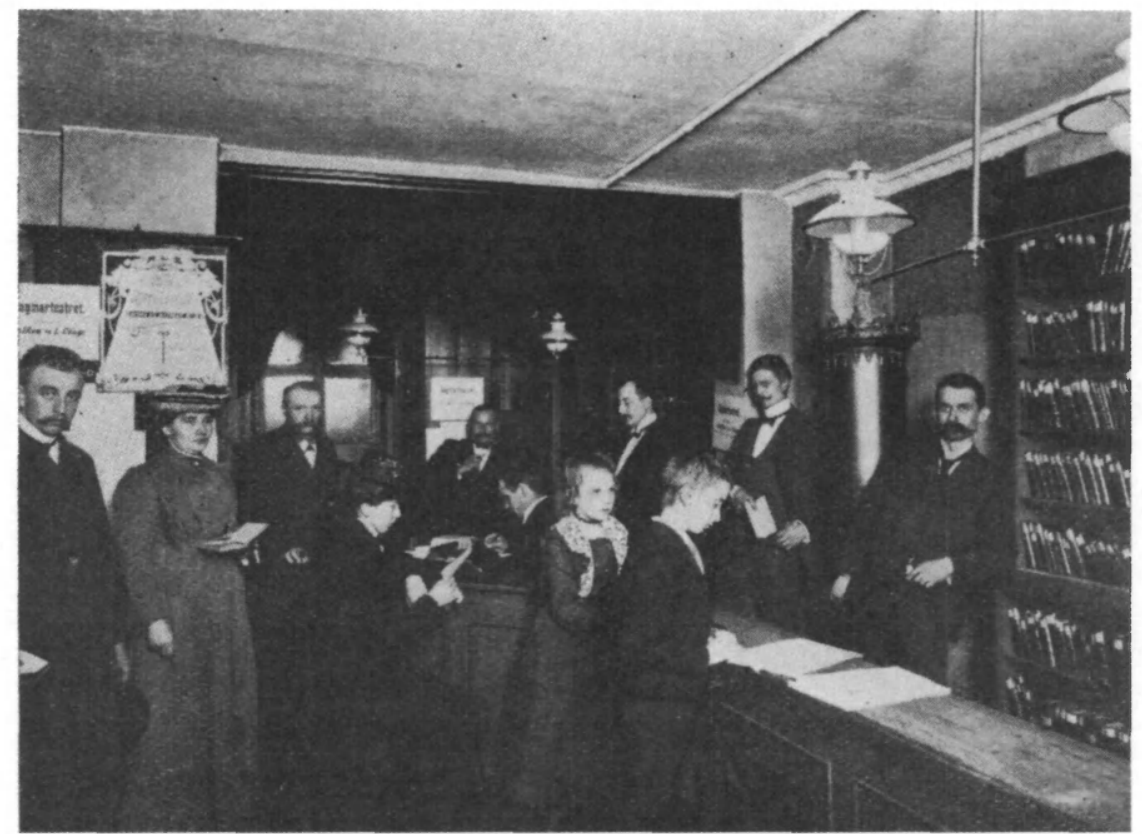

Ekspeditionslokalet $i$ Nansensgade i 1890'erne. (Efter Bruun, Georg og L. P. Hansen: Arbejdernes Lxeseselskab : Dets Historie og Minder, 1879-1929. Kbhvn. 1919)

bl.a. nedsatte billetpriser til teatre og museer. Derudover holdt Arbejdernes Læseselskab offentlige fester for at skaffe penge til selskabets kassebeholdning, der i starten ikke altid var lige god. I 1883 kneb det med at betale de $21 \mathrm{kr}$., som selskabet skyldte i husleje. Da selskabet kun havde $12 \mathrm{kr}$. i kassen, måtte bestyrelsen selv lægge det resterende beløb til.

Fra midt i 1880'erne begyndte det at gå fremad for selskabet, og fra en beretning fra selskabets generalforsamling i 1885 kan man se at medlemstallet var steget til 450 , at bogsamlingen var på 1.270 bind, og at der var 22 blade i læsestuen. Bladene på læsestuen var bl.a. de største københavnske aviser, en del af de større provinsaviser, en norsk og en svensk avis, samt et par udenlandske aviser. På dette tidspunkt havde læseselskabet endvidere flere udvalg, der tog sig af selskabets mange forskellige gøremål. Et forretningsudvalg tog 
sig af driften, bogudvalget tog sig af bogindkøb samt varetagelse af bogsamlingen, foredragsudvalget havde til opgave at skaffe foredragsholdere og oplæsere, og endelig var der et museumsudvalg, hvis formål var at arrangere besøg på seværdige steder.

Arbejdernes Læeseselskab havde lokaler i bl.a. Rømersgade og Gothersgade, før de i 1889 flyttede til Nansensgade, hvor selskabet boede de næste 27 år. Efterhånden som selskabet voksede, måtte disse lokaler dog også udvides og gøres i stand. I 1895 blev der ombygget og købt nyt inventar for $1.500 \mathrm{kr}$., og læsestuen blev ved denne lejlighed flyttet til 1. sal, mens bogsamlingen og ekspeditionen forblev i stueetagen.

Selskabet nåede sit højdepunkt omkring århundredskiftet, men omkring 1910 begyndte medlemstallet at dale. Det højeste antal medlemmer opnåede selskabet i 1910, hvor medlemstallet var på 2.475 personer. Selskabets højeste udlånstal forekom i 1903, hvor der blev udlånt 86.000 bøger. På baggrund af medlemsprotokollen fra 1909 blev der udarbejdet en statistik over medlemmerne, som viste hvordan de forskellige erhverv var repræsenteret i selskabet. Heraf fremgår, at der var 1.620 mandlige og 1.007 kvindelige medlemmer. Det kan også ses at de to største grupper blandt kvinderne var kasserersker, ekspeditricer, direktricer, telefondamer og bogholdersker; samt syersker og strygersker. For mændenes vedkommende var de to største grupper håndværkere og fabrikanter; samt handels- og kontorarbejdere. ${ }^{19}$ Selskabet havde desuden mange faglærte arbejdere som medlemmer, hvorimod de ufaglærte var svære at 'indfange'. ${ }^{20}$

\section{Arbejderforeningen af 1860}

Arbejderforeningen blev stiftet i 1860 af Christian Vilhelm Rimestad (1816-79), som var politiker og pædagog, og senere også redaktør. Han var lærer ved Borgerdydskolen i København og skolens bestyrer fra 1846 til 1853. Det fortælles om ham at han var en fortrinlig lærer, der med sin fortælleglæde, gode humør og legemlige styrke vandt drengenes interesse. Efter at have forladt Borgerdydskolen var han folketingsmand i perioderne 1854-66 og 1869-72. Som redaktør virkede han ved Dags-Telegrafen 1864-75 og ved Nationaltidende 1876-77. 
Rimestad gjorde en stor indsats i folkeoplysningens tjeneste, men da han ville stifte et bibliotek for arbejderne, var der mange der stod fremmede over for tanken om et 'folkebibliotek', og da hverken Det Kongelige Bibliotek eller Universitetsbiblioteket ville give ham bøger, henvendte han sig til Frederik d. 7, som skænkede ham dubletter fra den kongelige bogsamling. Og dette blev så starten på foreningens bibliotek, der åbnede i 1862 .

Rimestad sørgede med sin forening for undervisning til arbejderne, både i de elementære fag og i real- og latinskolens fag. Han arrangerede desuden grupperejser til Sverige og til verdensudstillingerne i London, Paris og Wien. Rimestad holdt selv flere foredrag i foreningen, bl.a. om de islandske sagaer, men han havde også sans for hvad der rørte sig i tiden. Derfor fik han også flere af tidens betydningsfulde personer til at holde foredrag, f.eks. H. C. Andersen. En anden foredragsholder var den kommunale læge F. F. Ulrik, der i 1865 holdt et foredrag om 'Småfolks selvhjælp og samarbejde i andre lande'. Efter mødet blev foredraget slået op hos $\mathrm{B} \& \mathrm{~W}$, hvilket resulterede i oprettelsen af Arbejdernes Byggeforening kort tid efter. ${ }^{21}$

\section{Håndverkerforeningen af 1840}

Anledningen til stiftelsen af Håndværkerforeningen i København var en kongelig resolution af 3 . april 1840, der befalede nedsættelsen af en komité, som skulle undersøge Københavns lavs- og korporationsvæsen. Dette førte til ytringer om at lavene burde slutte sig sammen i en forening, der kunne varetage deres tarv. Det blev overdraget til Johannes Lasenius Kramp, der i 1837 havde stiftet Snedkernes Tegneforening, at udfærdige en indbydelse til oprettelse af en håndværkerforening. Ved et møde i november 1840, i Den bestandig borgerlige Forenings lokaler i Vingårdsstræde, blev Håndværkerforeningen i København konstitueret.

Foreningen fik til at begynde med gratis lokaler i bagernes lavshus i Læderstræde 26, hvor den havde til huse frem til 1850, da foreningen lejede sig ind i skræddermestrenes lavshus på Gammel Mønt. Der blev indført underholdningsspil som skak og dam i lokalerne, og foreningen abonnerede $\mathrm{i}$ begyndelsen på Berlingske 
Tidende, Fadrelandet, Kjøbenhavnsposten, Den Frisindede og Corsaren. I 1842 oprettede foreningen sit bibliotek, som i begyndelsen kun var tiltænkt at indeholde litteratur, der omhandlede lavs- og næringsspørgsmål. Biblioteket voksede dog stærkt, og i 1844 kunne der udsendes en katalog.

I foreningens beretning fra 1844 siger J. L. Kramp bl.a. at han nærer 'en særlig interesse for et højere dannelsesliv i håndværkerforeningen' ${ }^{22}$ Kontingentet for at være medlem af foreningen blev ved begyndelsen sat til 3 mark pr. kvartal, men ved flytningen i 1850 blev beløbet forhøjet til 3 rigsdaler om året, for benyttelse af 'hyggeligt lokale, afbenyttelse af en stor del blade og tidsskrifter, samt udlån fra den nu af omtrent 600 bind bestående samling'. ${ }^{23}$ Fra 1852 skulle der tillige betales et indtrædelsesgebyr på 1 rigsdaler.

I Håndværkerforeningen foregik der mange diskussioner om lavstvang eller næringsfrihed, om lavene skulle bestå eller de skulle ophæves. En del lagde stor vægt på at fầ en reform vedrørende næringslivet, mens andre ikke ønskede det. I 1840 sagde Orla Lehmann fra Industriforeningen til Fadrelandet, at 'fuldkommen ophævelse af lavsvæsnet vil næppe gavne nogen'. J. L. Kramp ser dog ikke denne diskussion som foreningens eneste formål, men mener at foreningen skal virke både til 'åndens opbygning' og til 'materiel fordel for håndværksstanden'. Udfra det sidste synspunkt blev der nedsat en komité, der bl.a. skulle arbejde på at forbedre håndværkernes tarv. Det synspunkt er i øvrigt meget lig hovedformålet i Folkevenners Selskab.

Foreningen havde ved sit 25 års jubilæum ca. 400 medlemmer, og ved festen blev det bl.a. besluttet at forhøje medlemskontingentet med 1 rigsdaler om året. Disse penge skulle anbringes $i$ en byggefond, da foreningen snart måtte have nye lokaler. I 1868 købte Håndværkerforeningen en ejendom i Kronprinsessegade, der havde tilhørt Frimurerlogen, for 43.000 rigsdaler. Ved istandsættelsen af ejendommen kom foreningens daglige lokaler til at ligge i mezzaninetagen, hvor der blev indrettet læseværelse, billardværelse og spisestue. Biblioteket, der nu rummede 2.000 bind, blev indrettet på kvisten, og en oval stue på første sal blev benyttet til konversationsværelse. Foreningen rummede derudover også festlokaler, foruden 
lokaler i stueetagen der blev lejet ud. Tøjmager N. P. Christensen skænkede i 1887 foreningen en gave til bogsamlingen, bestående af 1.500 bind.

\section{Boghandler-Medhjolpernes Bibliotek}

Allerede i 1862 var der stiftet en medhjælperforening af selskabelig art, men den holdt kun nogle få år. I 1872 blev der imidlertid oprettet et boghandler-medhjælper-bibliotek, bl.a. på initiativ af Emil Bergmann. Biblioteket vakte opsigt og interesse i vid udstrækning, og havde i 12 år J. Salmonsen, der nok er mest kendt for sit leksikon, som formand. Biblioteket havde bl.a. faet sine bøger som gaver fra norske og danske forlag. Prisen for at benytte biblioteket var et årligt kontingent på 2 rigsdalere samt et indskud på 1 rigsdaler.

I bogbranchen var det mest almindeligt at bruge betegnelsen kommis i stedet for medhjælper, men efter oprettelsen af boghandler-medhjælper-biblioteket blev denne betegnelse ikke brugt ret meget mere. Boghandlermedhjælperne var næsten udelukkende mænd, og det vakte sensation da der til en fest, holdt af biblioteket, deltog en kvindelig medhjælper.

I 1883 blev medhjælperforeningen BMF stiftet på foranledning af Jul. Gjellerup, men til at begynde med tjente foreningen udelukkende et selskabeligt formål. Både J. Salmonsen og Immanuel Rée var med til at arrangere fester for BMF. I $1886 \mathrm{blev}$ de første skridt taget til at give foreningen et mere fagligt grundlag, og det tog rigtigt fart, da BMF i 1891 fik Chr. Kønig som formand. I 1898 blev biblioteket overtaget af BMF og ført videre som foreningens bibliotek.

\section{Konklusion}

I midten af 1800-årene havde København omkring 140.000 indbyggere og ud fra dette må man fastslå, at byens biblioteksforhold ikke var så ringe, som man måske umiddelbart havde kunnet forestille sig. Der var så godt som hele tiden 15-20 lejebiblioteker i byen, og desuden var der et stort antal klubber, læseselskaber og foreninger, hvortil der var knyttet et bibliotek.

Der må dog siges at være stor forskel på, hvor de forskellige samfundsgrupper lånte deres bøger. De lavere klasser hentede næsten 
udelukkende deres læsestof hos lejebibliotekerne. Dette gør sig specielt gældende i første halvdel af 1800-årene, hvor de forskellige klubber, selskaber og foreninger næsten alle var for borgerskabet. Blandt disse var f.eks. Læseselskabet Athenæum og Den bestandig borgerlige Forening, som også hørte til blandt de mange, der i deres indmeldelsesbestemmelser havde sørget for at kunne udelukke uønskede personer. Kontingentet hos mange af disse klubber og selskaber var i øvrigt så højt, at alene det udelukkede mange personer fra de lavere klasser. Men det skal dog fremhæves, at der også blandt det bedre borgerskab var en del der havde problemer med at betale de høje kontingenter.

Hos lejebibliotekerne blev der kun betalt for leje af bøger, hvorimod der hos de forskellige klubber, selskaber og foreninger blev betalt for meget mere. Disse steder fungerede nærmest som 'legepladser' for borgerskabets mænd. Det var her de mødtes, her de spillede billard, her de snakkede og diskuterede, og her de havde adgang til den nyeste litteratur. Man skal hen over midten af århundredet, før der kommer læseselskaber og foreninger for arbejderne, som f.eks. Arbejdernes Læseselskab. Som hos borgerskabets klubber var disse foreninger mere end blot et bibliotek. Det var steder hvor 'folket' kunne fă udvidet horisonten, forst og fremmest ved hjælp af litteraturen, men også gennem foredrag og udflugter.

Københavns Kommunes Folkebiblioteker var ikke de første folkebiblioteker der åbnede i København. I løbet af 1870'erne blev der åbnet fire folkebiblioteker i Københavns kommune og et i Frederiksberg kommune. Disse biblioteker var dog ikke i kommunalt eje, men var enten ejet af understøttelsesforeninger som Christianshavns og Brodersamfundets folkebiblioteker, eller de var privat ejet som Amagerlands og Nørrebros folkebiblioteker. Disse biblioteker havde, i modsætning til lejebibliotekerne, det syn på litteraturen, at den skulle virke i folkeoplysningens og folkeopdragelsens tjeneste. Det samme syn, som senere også findes i de kommunalt ejede folkebiblioteker.

Når man ser på den litteratur der var at finde på bibliotekerne, må man fastslå at der kunne være stor forskel, både hvad angår materialetyperne og udseendet. Når moralisterne talte om den smud- 
sige litteratur, der fandtes på lejebibliotekerne, var det i første omgang møntet på indholdet. Men også bøgernes udseende kunne på mange lejebiblioteker være særdeles utiltalende. Netop fordi det for ejerne først og fremmes gjaldt om at tjene penge, skulle bøgerne bruges så lang tid som overhovedet muligt. Dette har nok også været en af grundene til, at det bedre borgerskab ikke kom på mange af disse lejebiblioteker. I mange klubber og selskaber skiftedes de fleste bøger ud hvert år, så man hele tiden at havde den nyeste litteratur. Derved undgik man også lasede og beskidte bøger, og det er desuden tænkeligt, at man i de højere sociale lag har behandlet bøgerne bedre end blandt de lavere klasser.

De biblioteker, som fandtes i forbindelse med klubber, selskaber og foreninger, indeholdt som regel en stor del faglitteratur, hvorimod lejebibliotekernes udvalg stort set kun var skønlitteratur. Dette må igen ses i lyset af, at lejebibliotekernes ejere opfattede det som et erhverv, hvor der skulle tjenes penge, og det der var størst salg' i var skønlitteratur. Desuden lånte de lavere klasser næsten udelukkende skønlitteratur.

Der kunne i det hele taget være stor prisforskel, både hos lejebibliotekerne og hos de forskellige klubber og selskaber. Athenæum var absolut det dyreste selskab med sine 14 rigsdaler årligt, specielt set $\mathrm{i}$ forhold til Den nye Forening der kun kostede 2 rigsdaler om året, eller Læseforeningen af 1836 der kostede 7 rigsdaler årligt. Priserne hos arbejderforeningerne lå i den billigere ende, som hos f.eks. Socialdemokratisk Samfund og Arbejdernes Læseselskab, hvor det kostede 2,40 kr. om året.

Når det gælder lejebibliotekerne, kunne der være lige så stor forskel i priserne som for foreningernes vedkommende. I den dyre ende lå Andersens lejebibliotek, der skulle have 6 rigsdaler og 4 mark om året, hvorimod Bakkes lejebibliotek med sine 1 rigsdaler og 2 mark om året var det billigste. Mest almindeligt var det dog med priser mellem $2 \mathrm{rd} .4 \mathrm{mk}$. og $3 \mathrm{rd} .4 \mathrm{mk}$. om året, der som regel skulle betales kvartalsvis. Desuden kunne folk, som ikke havde så mange penge, vælge kun at betale for en uge ad gangen, når de en gang imellem fik råd til at låne en bog. På årsbasis var betalingen dog dyrere på denne måde. 
Bibliotekernes størrelse kunne variere en del, men for de københavnske bibliotekers vedkommende var det mest almindelige en samling på 2.000-4.000 bind. Dette gjaldt både for lejebibliotekerne og for klub-, selskabs- og foreningsbibliotekerne. Men det må også understreges, at der var foreninger der forstod at opbygge en stor samling, som f.eks. Kvindelig Læseforening der startede med ca. 1.000 bind i 1872 og 25 år efter havde 160.000 bind i sit bibliotek, hvilket på det tidspunkt må siges at have været lidt af en bedrift. Det er vel også derfor Rosine Heckscher stolt fortæller, at foreningen havde et større udlån end både Universitetsbiblioteket og Det Kongelige Bibliotek.

Der var væsentlig forskel på hvem der ejede bibliotekerne, specielt når man ser på lejebibliotekerne. Her var der folk både i og uden for bogbranchen. For boghandlernes vedkommende blev deres biblioteker i høj grad brugt for at tiltrække kunder, da man ikke blev rig af at have et lejebibliotek. Tværtimod var der mange der ikke kunne overleve mere end et par år, hvorefter deres lejebibliotek måtte sælges. Men det skal da også pointeres, at der var dem der havde lejebiblioteket hele deres levetid, og endda lod det gå i arv til andre. Der var også mange uden for bogbranchen, der oprettede et lejebibliotek. Måske fordi det ikke krævede meget andet end en bogsamling, som ikke behøvede at være særlig stor, før man kunne åbne et bibliotek. Mange lejede nemlig bøgerne ud direkte fra deres egen lejlighed.

Når det kommer til klubber, selskaber og foreninger, var der nok forskel på personerne bag oprettelsen, men i det store hele var de meget ens. De foreninger, klubber og selskaber, der tilhørte borgerskabet, kunne være mere eller mindre fine, og deres formål kunne være lidt forskellige af ordlyd, men brugerne kom fra stort set samme sociale lag, og formålet var som regel selskabelighed. Noget andet gjorde sig gældende for arbejderforeningernes vedkommende. Her kunne initiativtagerne være personer fra borgerskabet, der ønskede at være godgørende over for de lavere klasser, men de kunne også være personer fra arbejderstanden, som ønskede en forening for ligemænd. 


\section{NOTER}

1. Frøland, 1969.

2. Nielsen, 1960 , s. 442.

3. Nielsen, 1960 , s. 432.

4. Nielsen, 1960, s. 433-434.

5. Holst, 1980.

6. Bokkenheuser, 1923.

7. Nielsen, 1960 , s. 447.

8. Nielsen, 1960 , s. 453.

9. Steenstrup, 1917.

10. Bobé, 1919.

11. Bobé, 1919.

12. Davidsen, 1910.

13. Nielsen, 1960 , s. 454.

14. Lund, 1885.

15. Lund, 1885.

16. Bauer, 1890.

17. Arbejderkultur, 1982.

18. Bruun, 1929.

19. Biblioteker og studiekredse, i: Arbejderkultur, 1982.

20. Bruun, 1929.

21. København, før og nu - og aldrig, 1991.

22. Bauer, 1890.

23. Bauer, 1890 .

\section{LITTERATURLISTE}

Arbejderkultur 1870-1924. Redigeret af Gundhild Agger og Anker Gemzøe. København : Medusa. 1982. 547 s.

Banke, Jørgen: Folkebibliotekernes Historie i Danmark indtil år 1920 : I Omrids. København : Aug. Olsens Boghandel. 1929. 75 s.

Bauer, Adolf: Haandværkerforeningen i Kjøbenhavn 1840-1890 : En historisk Fremstilling. København : Nielsen og Lydiche. 1890. $188 \mathrm{~s}$.

Bobé, Louis: Karl van Manders Gaard alias Kongens Klub : Østergade 15 gennem fire Aarhundreder. København : Ole Haslund og Svend Heyman. 1919. 57 s.

Bokkenheuser, Knud: Klubliv : Et Bidrag til Københavns borgerlige Livs Historie. København : Gyldendalske Boghandel. 1923. 174 s.

Bruun, Georg og L. P. Hansen: Arbejdernes Læseselskab : Dets Historie og Minder, 1879-1929. København : Dansk Andels Trykkeri. 1919. 117 s. 
Davidsen, J.: Kjøbenhavnske Klubber og Selskabelige Foreninger. I: Fra det gamle Kongens Kjøbenhavn. København :Vinter. 1910.

Dolleris, Andreas: Danmarks boghandlere 1837-1918 : En personalhistorisk Haandbog. København : Nielsen og Lydiche. 1893. $223 \mathrm{s.}$

Frøland, Aleks.: Bøger, bogsalg, boghandlere omkring 1875. København : Forening for Boghaandværk. 1969. $188 \mathrm{~s}$.

Frøland,Aleks.: Dansk boghandels historie 1482 til 1945 : Med et kapitel om bogen i oldtid og middelalder. [København] : Gyldendal. 1974. s 157-237.

Fædrelandet, den 9 dec. 1851.

Holst, Poul:Antikvarboghandel i Danmark 1640-1980. [København]. 1980. S. 2242.

Hvenegaard Lassen, H.: De danske folkebibliotekers historie 1876-1940. København : Dansk Bibliografisk Kontor. 1962. S. 1-67.

Kirkegaard, Preben: Folkebibliotekerne i Danmark. København : Det danske Selskab. 1948. S. 1-22. (Danmarks folkelige kulturindsats. Grundbøger til brug for oplysning om Danmark)

Kjøbenhavns Adressebog for 1856. Red. af I. Levin. København : Iversen. 1956. XIV, 286 s.

Kraks Vejviser. 1833-1924.

Kräyenbühl, Margit: Kvindelig Læseforening 1872-1962 : En redegørelse for Kvindelig Læseforenings virksomhed med en registratur over foreningens arkiv 1872-1962. København : Danmarks Biblioteksskole. 1978. S. 25-36. (Upubliceret hovedopgave)

København, før og nu - og aldrig : En billedkavalkade om København inden for voldene og søerne. Redaktion og billedtekster: Bo Bramsen. København : Forlaget Palle Fogtdal A/S. 1991. Bind 1-11.

Lund, Holger: Selskabet for Borgerdyd : Et Bidrag til dansk Kulturhistorie. København: Otto B. Wroblewskys Forlag. 1885. $171+$ XV s.

Nielsen, Helge: Folkebibliotekernes forgængere : Oplysning, almue- og borgerbiblioteker fra 1770erne til 1834. København : Dansk Bibliografisk Kontor. 1960. Ss. 9-20 og 413-533.

Schacht, Sigrid: Dansk bibliotekshistorie. [København]: Danmarks Biblioteksskole. 1983. S. 72-88. (Intern lærebog, utrykt)

Steenstrup, Johannes: Dansk Kvindesamfund og dets Virksomhed. Kvindelig Læseforening. I: Den danske Kvindes Historie fra Holbergs tid til vor 17011917. København : H. Hagerups forlag. 1917. S. 157-163.

Vasegaard, Søren: Fra Bakkes Boghandel. I. Bidrag til Belysning af kjøbenhavnske Bogforhold ved Midten af det 19. Aarhundrede. København : H. Chr. Bakkes Boghandel. 1932. 32 s. 
Småtryk (Det Kongelige Bibliotek)

Fortegnelse over Boghandler-Medhjælper-Bibliotheket. København. 1885.

Fortegnelse over Bogsamlingen i Arbejderforeningen af 1860. København. 1878.

Fortegnelse over Bogsamlingen i Kongens Klub. København. 1867.

Fortegnelse til det af Foreningen til Lærlinges Uddannelse oprettede Bibliothek. København. 1878.

Fortegnelse over Kjøbenhavns Politis Bogsamling: København. 1872.

Fortegnelse over Det Sjællandske Jernbanepersonales Bogsamling. København. 1878 .

Fortegnelse over det Skandinaviske Selskabs Bogsamling. København. 1852.

Katalog over Bibliotheket for underholdende Læsning. Snedkernes Tegneforening af 1837. København. 1872.

Katalog over Bøgerne i Arbejdernes Læseselskab. København. 1882.

Katalog for Den bestandig borgerlige Forening. København. 1879.

Katalog over "Brodersamfundets" Folkebibliothek. København.

Katalog over det danske Missions Selskabs Bogsamling. København. 1878.

Katalog over det dels Læseselskabet for Kunstnere og Haandværkere dels den polytekniske Læreanstalt tilhørende Bibliothek. København. 1841.

Katalog over den borgerlige Læseforening. København. 1849.

Katalog over Haandværkerforeningens Bibliothek. København. 1851.

Katalog for den nye Forening. København. 1840.

Katalog for Læseindretningen fra 1826. København. 1835.

Kristelig Forening for unge Mænd. Foreningsbibliothek. København. 1880.

Love for Læseforeningen af 1836. København. 1839.

Love for Læseselskabet Clio. København. 1819.

Love for Læseselskabet "Pontianus”. København.

Love for Socialdemokratisk Samfunds Bibliothek. København.

Nørrebroes billigste Folkebibliothek. København. 1881.

\section{BILAG 1 - Lejebiblioteker 1863-1885}

Navne og adresser er fundet i Kraks vejviser. Fortegnelsen omfatter alene lejebiblioteker, som eksisterede i 1863 eller senere. I årene 1857-1862 samt før 1833 kan man i vejviseren ikke slå op under 'lejebiblioteker' eller andre 'folkebiblioteksbetegnelser'.

Ved møntreformen i 1875 ændredes det danske pengesystem. Det gamle system med 1 rigsdaler à 6 mark à 16 skilling blev erstattet af kronesystemet.Ved omregning var forholdet følgende: 1 rigsdaler $=2$ kroner; 1 mark $=33$ øre; 1 skilling $=2$ øre. 
Andersen, A.

Åbnet 1874, lukket 1875. Hauserplads 12. Åbent alle hverdage kl. 9-12 og 1417. Bestand 5000-6000 bind. Pris for 1 bog: $1 \mathrm{mk}$. pr. uge, $4 \mathrm{mk}$. pr. md., 1 rd. 4 mk. pr. kvt. Højere pris ved leje af flere bøger. Depositum for hver bog: 2 rd. eller en ting til samme værdi. Der kan ombyttes 1 gang daglig.

Bakke, H. C. (boghandler) Åbnet 1841, lukket 1922. Ejet 1841-84 af H. C. Bakke, 1884-99 af A. Richter og 1899-1922 af J. E. Wismann. Møntergade 27. Åbent 9-20 alle hverdage. Pris for 1 bog: 8 sk. pr. uge, 1 mk. 8 sk. pr. md., 2 mk. pr. kvt. For 2 bøger: 12 sk. pr. uge, 2 mk. pr. md., 1 rd. pr. kvt. For 3 bøger eller flere betales i forhold dertil. Bøgerne kan byttes 2 gange daglig. Depositum for hver bog: 2 rd. eller en ting til samme værdi.

Boller, A. F (antikvarisk boghandler og bogbinder) Åbnet 1862, lukket 1869. St. Kongensgade 99.

Bruun, $\mathrm{H}$.

Åbnet 1850, lukket 1864. Kompagnistræde 4.

Børresen, P. (bog- og papirhandler) Åbnet 1862, lukket 1877. Brogade 14 (gaden nedlagt i 1930'erne).

Cohen, Frederikke (sproglærerinde) Åbnet 1876, lukket 1884. Frederiksholm Kanal 2.

Conradsen, J. P. (boghandler) Åbnet 1851, lukket 1871. Knabrostræde 13.

Floor, C. M. E. Åbnet 1868, lukket 1885. Skindergade 5 .

Floor, J. P. N. Åbnet 1862, lukket 1867. Skindergade 22.

Hansen, Anders Åbnet 1861, lukket 1865. St. Regnegade 24 .

Hansen, P. C.

Åbnet 1868, lukket 1876. St. Helliggeiststræde 19 (efter 1881 Valkendorfsgade).

Jordan, H. Ludvig (boghandler)

Ejet 1838-1898 af H. L. Jordan, 1898 overtaget af C. Flor og P. Engberg, lukket 1916. Silkegade 4, flyttet hertil i 1858. Åbent alle hverdage kl. 9-20. Bestand ca. 4000 bd. på dansk og ca. 500 bd. på engelsk. Pris for 1 bog: 12 sk. pr. uge, $2 \mathrm{mk}$. pr. md., $5 \mathrm{mk}$. pr. kvt. Pris for 2 bøger: $1 \mathrm{mk}$. pr. uge, $3 \mathrm{mk}$. pr. md., 8 mk. pr. kvt. Der kan byttes så ofte det ønskes. Depositum for hver bog: 1 rd. eller en ting af samme værdi.

Jordan, J. S. (jomfru)

Åbnet 1848, lukket 1892. Pilestræde 13. Åbent alle hverdage kl.9-20. Bestand 3000-3500 bind. Pris for 1 bog: 8 sk. pr. uge, 24 sk. pr. md., 4 mk. 8 sk. pr. 
kvt. Pris for 2 bøger: 12 sk. pr. uge, 2 mk. pr. md., 1 rd. pr. kvt.

\section{Kauffmann}

Eksisterede kun 1865. Kronprinsessegade 6.

Kjeldsen, Georg (Riiseske Abonnementbibliotek)

Åbnet 1835, lukket 1892. Ejet 1835-55 af J. Riise og 1855-92 af G. Kjeldsen.

Skindergade 21, tidl. Nørregade.

Langkjær, M. A.

Åbnet 1884, lukket 1892. L. Torvegade 32 (senere Torvegade). Pris for 1 bog: 20 øre pr. uge, 65 øre pr. md., 1,65 kr. pr. kvt., 6 kr. pr. år. Pris for 2 bøger: 30 øre pr. uge, 1 kr. pr. md., 2,65 kr. pr. kvt., $10 \mathrm{kr}$. pr. år. Pris for 3 bøger: 40 øre pr. uge, 1,25 kr. pr. md., 3,25 kr. pr. kvt., 13 kr. pr. år.

Leisner (frøken)

Åbnet 1870, lukket 1876.V.ærnedamsvej 14.

Levin, Henriette

Eksisterede kun 1871. Adelgade 7.

Levin, Zerline (enke)

Åbnet 1865, lukket 1901. Klosterstræde 23, stuen. Åbent alle hverdage kl. 920. Bestand 1000-1500 bd. Pris for 1 bog: 8 sk. pr. uge, 24 sk. pr. md., 64 sk. pr. kvt. Pris for 2 bøger: 12 sk. pr. uge, 32 sk. pr. md., 1 rd. pr. kvt. Depositum for hver bog: 1 rd. eller en ting af samme værdi. Der kan byttes så ofte det ønskes.

Loria, Sally J.

Åbnet 1857, lukket 1865. Vesterbrogade 84. Åbent alle hverdage kl. 8-18. Bestand ca. 2000 bd. 14 dages lån, nye bøger dog kun 4 dage. Pris for 1 bog: 24 sk. pr. md., 64 sk. pr. kvt., 2 rd. 32 sk. pr. år. Pris for 2 bøger: 36 sk. pr. md., 1 rd. pr. kvt., 3 rd. 48 sk. pr. år.

Meyer, L. (boghandler)

Åbnet 1862, lukket 1873. Borgergade 11 .

Mohr, J. F.

Åbnet 1880, lukket 1895. Nørrebrogade 23.

Mortensen, R. C.

Åbnet 1861, lukket 1865. Grønnegade 16.

Nielsen, F.V. (detailhandler)

Åbnet 1861, lukket 1869. Larsbjørnstræde 25 .

Offesen, C.

Åbnet 1862, lukket 1866. Adelgade 64 .

Olsen, F. F.

Åbnet 1881, lukket 1889. Frederiksborggade 28 .

Petersen, Th.

Åbnet 1882, lukket 1886. Lyngby. 
Popp, $M$.

Åbnet 1880, lukket 1882. St. Kongensgade 46.

Rée, Immanuel

Åbnet 1881, lukket 1886. L. Kirkestræde 5.

Rubin, D. (boghandler)

Åbnet 1853, lukket 1884 . Skindergade 23. Lejebibliotek for romaner, skolebøger og videnskabsværker.

Stjerneholm, M.

Åbnet 1862, lukket 1865. St. Regnegade 2 .

Søborg, J. F. (boghandler, klasselotterikollektør, D.M.)

Åbnet 1847, lukket 1889; ca. 1880 overtaget af andre og kørt videre som Søborgs efterfølger. L. Helliggeiststræde 13 (efter 1881 Niels Hemmingsensgade), ved overdragelsen ca. 1880 flyttet til Pilestræde 42 . Ăbent alle hverdage kl. $8-20$. Bestand: 1000-1500 bd. Pris for 1 bog: 6 sk. pr. uge, $1 \mathrm{mk} .8 \mathrm{sk}$. pr. md., 4 mk. pr. år. Pris for 2 bøger: 10 sk. pr. uge, 2 mk. pr. md., 1 rd. pr. år. Depositum for hver bog: 1 rd. eller en ting af samme værdi.

Thaarup, E. L.

Åbnet 1862, lukket 1867. St. Helliggeiststræde 20 (efter 1881 Valkendorfsgade).

Thomsen, F.V.

Åbnet 1864, lukket 1866. Vesterbrogade 52.

Ørfeldt, T. C. (boghandler)

Åbnet 1870 , lukket 1880 . Vingårdsstræde 9 .

\section{BILAG 2 - Folkebiblioteker i København 1870-1885}

Betegnelsen brugtes om biblioteker med et mindre/ikke kommercielt sigte, som lagde vægt på at litteraturen skulle være oplysende og belærende. Bibliotekerne blev styret af en bestyrelse. Der er ikke fundet biblioteker af denne type før 1870

Amagerlands Folkebibliotek i Sundbyvester

Ăbnet 1877, i 1902 indlemmet i Københavns Kommunes Folkebiblioteker. Flyttede i 1899 til Amagerbrogade 64. Åbent mandag og torsdag kl. 19-21, lørdag kl. 9-11. Bestand 2200 bd. (1879). For benyttelse betaltes 20 øre pr. md., 50 øre pr. kvt., 1,50 kr. pr. år. Bestyrelse: fabrikant Julius Holmblad (formand), sognerådsmedlem O. Jansen, sognerådsmedlem (E.M. Krogh), sognefoged Jan Pettersen, grosserer C. E. Petersen, skoleinspektørVilhelm Petersen, kaptajn Ludvig Scheel.

Brodersamfundets Folkebibliotek

Åbnet 1873, lukket 1886. 1873-77 i Adelgade 96, derpå i Søetatens drenge- 
skole i Krokodillegade. Åbent onsdag og søndag kl. 19-21. Bestand 1800 bd. (1879). For benyttelse betaltes 20 øre pr. md., 50 øre pr. kvt., 1,50 kr. pr. år. Bestyrelse: pastor D. C. Prior (formand), typograf C. Andersen.

Christianhavns Folkebibliotek

Åbnet 1875, lukket 1887. Bestemt for Christianshavns uformuende befolkning. Sankt Annægade 39. Åbent mandag, onsdag og lørdag kl. 18-20. Bestand 1800 bd. (1876). For benyttelse betaltes 16 øre pr. md., 40 øre pr. kvt., 1,25 kr. pr. år. Bestyrelse: pastor P. A. Fenger, pastor J. C. Holck, pastor V. Munch, skoleinspektør J. Helms, vinhandler C. Bagge, overretssagfører O. Krarup.

Frederiksberg Sogns Folkebibliotek

Åbnet 1870, lukket 1886. Tilhørte sognets understøttelsesforening. 1870-73 i Vesterbrogade 70,1873-79 iVesterbrogade 76, derpå Gasværksvej 1. Åbent alle hverdage kl. 18-20. Bestand 3000 bd. (1879). For benyttelse betaltes 20 øre pr. md., 50 øre pr. kvt., 1,50 kr. pr. år. Bestyrelse:justitsråd, bibliotekar Bruun, forretningsfører Cold, redaktør Møller-Holst, fuldmægtig A. Johansen, F. C. Trier, underbibliotekar Bahl.

Nørrebroes billigste Folkebibliotek

Eksisterede i 1880 'erne. Slotsgade 8, stuen. Bestand 800 bd. For benyttelse betaltes 13 øre pr. uge, 45 øre pr. md., 1,25 kr. pr. kvt.

\section{BILAG 3 - Klubber og læseforeninger i København 1850-1885}

Den bestandig borgerlige Forening

Også kaldet det bestandig borgerlige Selskab. 14 dages lån. Der kan lånes 2 bøger ad gangen.

Den borgerlige Læseforening

Bestand ca. 4000 bd. En stor del dansk litteratur, såsom B. S. Ingemann, H. C. Andersen og St. St. Blicher.

Det danske Missions Selskabs Bogsamling Mest missionsskrifter og andre kristelige værker.

Kjøbenhavns Læsesalon

Kongens Klub

Åbent mandag og torsdag kl. 13-14. Bøger på dansk, tysk, engelsk og fransk. 14 dages lån. Der kan lånes 2 bøger ad gangen.

Kvindelig Læseforening

Åbent hverdage kl. 11-15 og kl. 16-19. Intet udlån fra kl. 16 på foredragsdage. 14 dages lån på skønlitteratur. $1 \mathrm{mds}$. lån på andet materiale.

Læseindretningen fra 1826

Danske, tyske, engelske og franske bøger; både skøn- og faglitteratur. 
Kirsten Mosolff - Bibliotekstilbud i Kobenhavn 1850-1885

Læseforeningen af 1836

Kontingent: 7 rd om året. 8 dages lån. Encyclopædier og ordbøger skal forblive i læsestuen. Bøger og pjecer overgår efter 6 uger i læsestuen til biblioteket. Hvis der fjernes bøger fra læsestue eller bibliotek, betales 5-15 rd. i bøde.

Læseselskabet Athenæum

Læseselskabet "Pontianus"

Den nye Forening

Danske, tyske og franske bøger; både skøn- og faglitteratur. 8 dages lån på nye bøger, 14 dages lån på gamle bøger. Der kan lånes 3 bøger ad gangen. Kontingent: $2 \mathrm{rd}$. om året, der betales med $1 \mathrm{mk}$. om måneden. Livsvarigt medlemskab ved betaling af et engangsbeløb på $30 \mathrm{rd}$.

Selskabet for Borgerdyd

Det Skandinaviske Selskab

Næsten kun bøger på svensk. Kun for medlemmer. 14 dages lån. Der må lånes 1 bog ad gangen. Bøde ved for sen aflevering: 6 sk. Erstatning ved tab.

BILAG 4 - Arbejder- og håndværkerforeninger i København 1850-1885

Arbejderforeningen af 1860

Ảbent søndag kl. 13-15. For alle medlemmer med lånerkort. 14 dages lån. Der kan lånes 1 bog ad gangen. Bøde ved for sen aflevering: 10 øre.

Arbejdernes Læseselskab

Ăbent hverdage kl. 19-22. Kontingent: 20 øre pr. md. 4 ugers lån. Der kan lånes 1 bog ad gangen. Bøde ved for sen aflevering: 10 øre.

Boghandler-Medhjælpernes Bibliotek

Ảbent kl. 20.30-22. Indskud: 1 rd. Kontingent: 2 rd om året. Der kan lånes 2 bøger ad gangen.

Foreningen til Lærlingeuddannelser

Åbent søndag kl. 12-14 og 17-19. For medlemmer. 3 ugers lån. Der kan lånes 2 bøger ad gangen. Bøde ved for sen aflevering: 10 øre. Bogfortegnelsen (kataloget) koster 25 øre.

Håndværkerforeningen af 1847

Både skøn- og faglitteratur, bl.a. historie, geografi, økonomi, romaner og noveller. Mest på dansk.

Kjøbenhavns Politis Bogsamling

Åbent søndag kl. 10-16. For ansatte i politiet. Mest litteratur på dansk. 14 dages lån. Der kan lånes 1 bog ad gangen. Bogfortegnelsen koster $16 \mathrm{sk}$.

Kristlig Forening for unge Mænd

Ăbent torsdag og søndag kl. 20-21.30. Rejseskildringer, romaner og kristlig 
litteratur på dansk. Kontingent: $1 \mathrm{kr}$ om året, betales med 25 øre pr. kvartal. 3 ugers lån. Der kan lånes 2 bøger ad gangen. Bøde ved for sen aflevering: 5 øre.

Læseselskabet for Kunstnere og Haandværkere

Det Sjællandske Jernbanepersonales bogsamling

Mest skønlitteratur på dansk.

Snedkernes Tegneforening af 1837

Åbent torsdag kl. 20-22. 3 ugers lån. Bøde ved for sen aflevering: 6 sk. for 1 bog, 4 sk. pr. stk. ved flere bøger.

Socialdemokratisk Samfunds Bibliotek

Kun for medlemmer af det Socialdemokratiske Arbejderparti. Pris: 5 øre ugentlig for hver bog. 14 dages lån. Bøde ved for sen aflevering: 5 øre for 1 uge, 15 øre for 2 uger, derover 50 øre. 